\title{
Occurrence and Fate of Emerging Pollutants in Water Environment and Options for Their Removal
}

\author{
Ionela Cătălina Vasilachi ${ }^{1}$, Dana Mihaela Asiminicesei ${ }^{1}$, Daniela Ionela Fertu ${ }^{1}$ and Maria Gavrilescu ${ }^{1,2, *}$ \\ 1 Department of Environmental Engineering and Management, "Cristofor Simionescu" Faculty of Chemical \\ Engineering and Environmental Protection, "Gheorghe Asachi" Technical University of Iasi, 73 Prof. Dimitrie \\ Mangeron Blvd., 700050 Iasi, Romania; ionela-catalina.vasilachi@student.tuiasi.ro (I.C.V.); \\ dana-mihaela.asiminicesei@student.tuiasi.ro (D.M.A.); danafertu2004@yahoo.com (D.I.F.) \\ 2 Academy of Romanian Scientists, 3 Ilfov Street, 050044 Bucharest, Romania \\ * Correspondence: mgav@tuiasi.ro
}

Citation: Vasilachi, I.C.;

Asiminicesei, D.M.; Fertu, D.I.;

Gavrilescu, M. Occurrence and Fate of Emerging Pollutants in Water Environment and Options for Their Removal. Water 2021, 13, 181.

https://doi.org/10.3390/w13020181

Received: 13 October 2020

Accepted: 9 January 2021

Published: 13 January 2021

Publisher's Note: MDPI stays neutral with regard to jurisdictional clai$\mathrm{ms}$ in published maps and institutional affiliations.

Copyright: $\odot 2021$ by the authors. Licensee MDPI, Basel, Switzerland. This article is an open access article distributed under the terms and conditions of the Creative Commons Attribution (CC BY) license (https:// creativecommons.org/licenses/by/ $4.0 /)$.

\begin{abstract}
Emerging pollutants (EPs) are chemicals known to cause major impacts on the terrestrial, aquatic life and human health as a result of their chronic and acute toxicity. Although lots of studies on EPs behavior in the aquatic environment are currently available in literature, an urgent requirement exists to complete toxicological studies and develop and implement efficient and ecological methods for their removal. This paper raises some relevant problems related to water environment pollution with EPs, the risks they can generate for aquatic life and humans and opportunities to reduce the effects of pollution by EPs removal. Categories of emerging chemicals of concern in the environment, their sources, fate and impacts, with some examples are discussed. Organic UV filters are shortly presented as a relative new EPs category, with a focus on the need to develop extensive experimental studies on their environmental occurrence, fate and removal. Furthermore, sources for the aquatic environment resulting from discharging EPs directly into rivers from wastewater treatment plants are examined. The incidence of environmental and human health risks related to EPs is also considered. The removal of EPs from the environment as a solution to risk mitigation is addressed, with emphasis on several non-conventional processes involving biological removal of EPs. The paper provides a critical look at the current challenges posed by the presence of emerging pollutants in the aquatic environment, with critical comments and recommendations for further research to reduce the impact of EPs on water and human health and improve the performance of developed methods for their removal.
\end{abstract}

Keywords: adsorption; risk; wastewater; persistence; constructed wetlands; membrane biological reactor; hybrid treatment

\section{Introduction}

Environmental pollution has become one of the most challenging and everyday problem. With the industrialization and urbanization, the degradation of the environmental quality has evolved worryingly. Diverse categories of pollutants, as persistent inorganic (e.g., heavy metals) and organic (pharmaceuticals, pesticides, endocrine disrupting agents, personal care products, etc.) are a serious problem at global level, since they can affect both flora and fauna and human health [1-3].

Water, an essential resource for life on Earth, is one of the most vulnerable environmental compartments; consequently, water pollution has become a matter of utmost interest and concern worldwide. The 3rd World Water Forum in Kyoto, Japan has drawn attention since 2002 to the fact that every day about 2 million tons of pollutants of various categories (sewage, industrial and agricultural waste) are discharged into water around the world, a quantity that almost equals the weight of the terrestrial population, thus generating nearly $1500 \mathrm{~km}^{3}$ of wastewater [4,5]. In this study, we present the current state of the art on the occurrence, fate, risks and removal of emerging pollutants in water and the 
challenges for improving existing technologies to remove emerging pollutants as a basis for sustainable water resources management.

Studies published in literature emphasize that pollutants in the aquatic environment are characterized by an interesting dynamic regarding their categories, which change over time. It is, therefore, necessary to intensify research efforts and resources invested in identifying all possibilities to reduce the impacts and risks generated by water pollution, with implicit effects on human health, because persistent pollutants possess the capacity to get involved in food chain. The improvement of the detection techniques of some substances in the aquatic environment in recent decades has led to the identification of an increasing number of pollutants and their transformation products, which were not previously known in water bodies $[6,7]$. These compounds are recognized as emerging pollutants, which include products used daily in households, industry and other anthropogenic activities (surfactants and degradation products, pharmaceuticals and personal care products, gasoline additives and plasticizers, etc.). Literature studies suggest that current mechanisms for collecting specific information on the dynamics of emerging pollutants in water need to be updated and refined to avoid risks for water quality, flora and fauna in river basins [3,4]. This is necessary as the Water Framework Directive [8] requires member states to establish national programs containing watching lists for emerging pollutants (EPs); these pollutants require additional attention because of the risks mentioned above which they can generate at any time. The issue of emerging pollutant is a permanent challenge, because the monitoring costs are not negligible at all and can enforce limits on the number of monitored substances. Really, the establishment of extensive databases on emerging pollutants is an open issue, as they would provide data on the properties of EPs and their metabolites and for motivating member states to include EPs in water quality surveys [4]. These approaches would be prerequisites for the development of appropriate water treatment and sustainable methods for the removal of these pollutants from the environment, fundamental for human and environmental health protection $[3,4,9]$.

This paper reports a critical analysis on the occurrence, fate and properties of EPs, highlighting laboratory and field studies on the removal of these contaminants from aquatic environments and identifies possible limitations and gaps in the implementation of EPs removal technologies. Then, information is provided on the factors that may contribute to or adversely affect the processes discussed. Finally, current knowledge gaps, future research directions and critical understanding of state of the art on single treatment processes and/or combinations of biological and physical processes in hybrid systems for increasing the efficiency of EPs removal are shown.

\section{Emerging Pollutants in Water Environment}

As a result of the continuous development of anthropogenic activities (industry, agriculture, health), the production and use of chemicals known as "emerging pollutants" and/or "contaminants of emerging concerns" have increased. The first EPs were discovered in early 1800s in aquatic environments [10]. The presence of emerging pollutants in the environment is the result of the uncontrolled urbanization, development of industry, health care activities essential to support human well-being, agriculture and transport and include a wide range of substances produced by humans, considered indispensable for the modern society $[3,11]$. EPs are synthetic persistent organic chemicals, which are not normally monitored in the environment, but which can create adverse effects on the environment and human health. According to the NORMAN database, (www.norman-network.net), there are more than 700 compounds grouped in 20 classes of emerging pollutants: "surfactants, antibiotics and other pharmaceuticals, steroid hormones and other endocrine-disrupting compounds (EDCs), fire retardants, sunscreens, disinfection byproducts, new pesticides and pesticide metabolites, naturally-occurring algal toxins", etc. [4,12]. Figure 1 evidences some groups of emerging pollutants that can be found in the environment. 


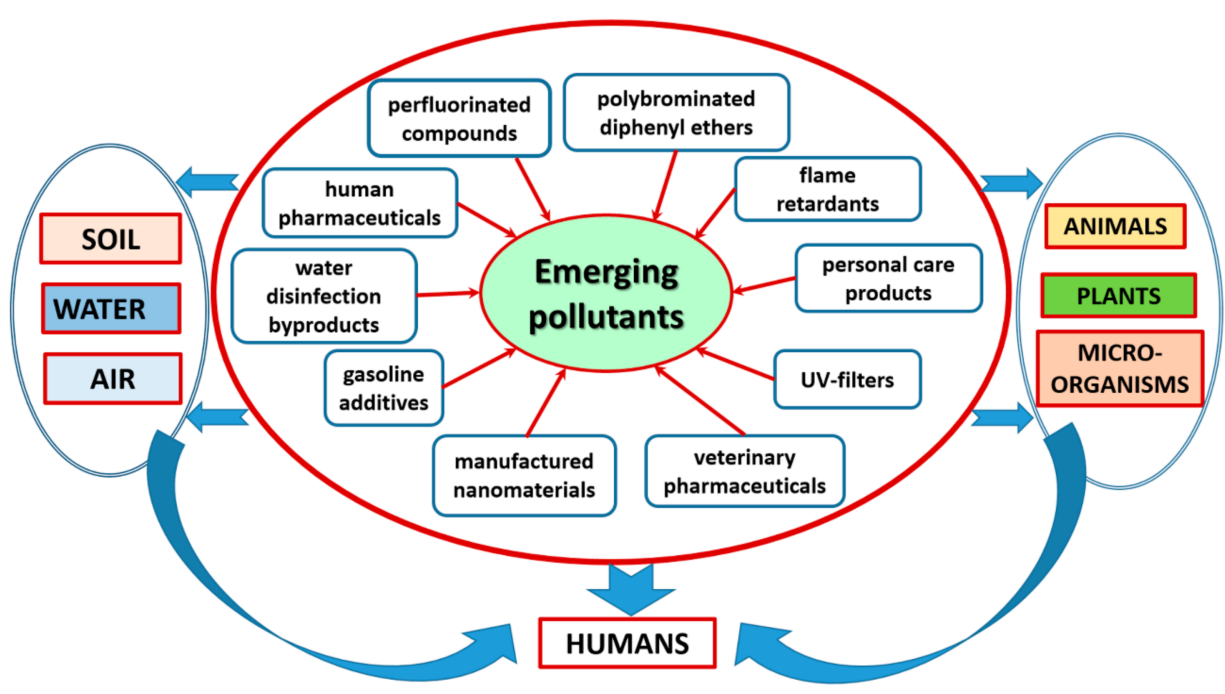

Figure 1. Categories of emerging pollutants that impact on soil, air, water, animals, plants, microorganisms and humans (adapted upon [13-16]).

There are numerous studies and research on the occurrence, sources behavior, impacts and risks of EPs in the environment [3,14-16], but currently, comprehensive data on their toxicity are not available. This is due to poor information, triggered by the complex characteristics of the emerging pollutants in the environment, related to their physicochemical properties, causing unexpected behavior in water, soil and air [3,17]. EPs can be found in water in concentrations over a wide range, of the order of $n g / L-g / L$, and their effects on living organisms are associated with toxicological effects, endocrine disruption, acute and chronic toxicity, resistance of microorganisms to antibiotics, threats on human health $[4,18]$.

There is another group of pollutants denoted as "contaminants of emerging concern", which are "well-known chemicals that have been used for decades (some of which are persistent or pseudopersistent) in different applications and, cumulatively released into the environment, and the by-products of their environmental degradation, that are now being recorded in surface and groundwater resources, as well as in soils and sediments". This term of "contaminants of emerging concern" is habitually used when there is very little information about the magnitude and frequency of risks posed by this category of pollutants in the environment and human health $[17,19,20]$.

Although some emerging pollutants have existed in the environment for several years, their qualitative and quantitative occurrence have been analyzed only recently, and they might be hazardous for ecosystems [3,21]. The new analytical techniques (e.g., liquid chromatography coupled to mass spectrometry [LC-MS], tandem MS [MS2] or LC-MS2 and others) recently developed and applied made promising the detection of extremely low concentrations ( $\mu \mathrm{g} \mathrm{L}^{-1}$ or ng L ${ }^{-1}$ ) of these compounds in liquid and solid matrices. By applying these techniques, it was possible to detect and quantify around 3000 biologically active chemical compounds in the environment [22-25].

Many EPs are not subject to standards and regulations due to lack of information on the effects of chronic exposure. Pharmaceutical products (CECs), personal care products (PPCPs) and flame retardants are some of the most commonly detected EPs in the environment $[3,17]$ (Table 1). Compounds that affect the endocrine system (EDC) are some of the most explored emerging pollutants (Figure 1); more than 200 individual compounds have been identified, and a number are monitored so far [3]. Currently, more than 3 million tons of phthalates are produced in the world, as chemical compounds that have also been used for over half a century as plasticizers in plastics or as fixing agents in cosmetics [26-28]. 
Table 1. Categories of emerging chemicals of concern in the water environment, with some examples [3,14-16].

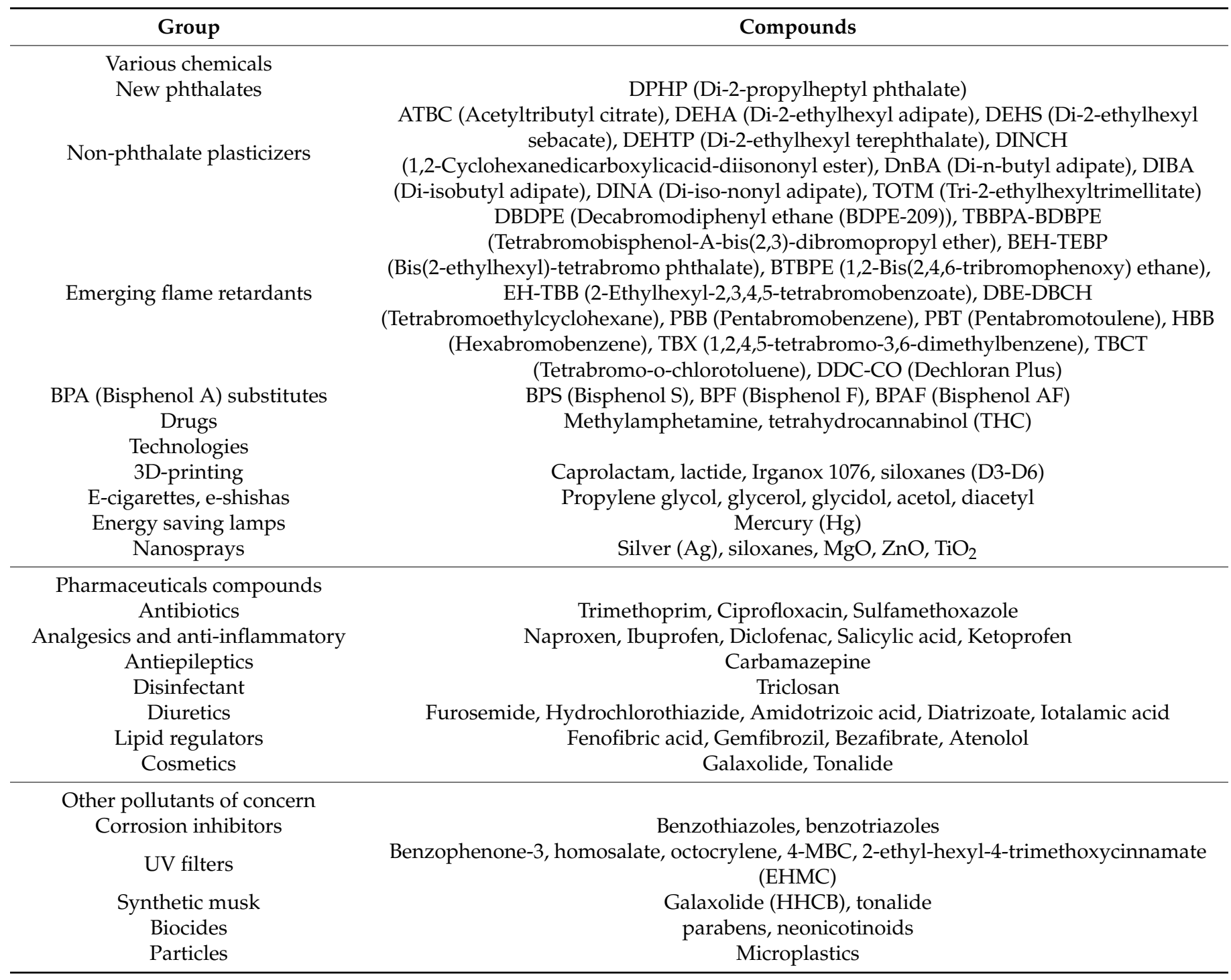

Among emerging pollutants, a category of wide interest is represented by pharmaceuticals, due to the large volume used to treat a wide variety of diseases and their very diverse physico-chemical and biological characteristics. Almost all classes of drugs, a large part of a persistent nature, have been detected in effluents [29]. Pharmaceutical compounds (entailing different classes: hormones, anti-inflammatory, anti-epileptic, statins, antidepressants, beta-blockers, antibiotics, contrast agents, etc.), after administration are largely excreted in the original form or as metabolites and can be found in urban wastewater, hospital sewers and surface waters [2,30-32]. They can also reach groundwater or even drinking water, as well as the soil from irrigation water. Antibiotics in the environment seem to spread in increasing quantities, encompassing a growing diversity of compounds. Recent studies found that antibiotic concentrations in some rivers of the world exceed the "safe" levels up to 300 times [33-35]. According to the World Health Organization, the biggest threat to global health, food security and development is antibiotic resistance. An increasing number of infections and diseases are difficult to be treated, as antibiotics used to treat them become less effective as a result of environmental pollution [36,37].

In the category of emerging pollutants, the micropollutants (EMPs) are "anthropogenic chemicals that occur in the (aquatic) environment well above a (potential) natural background level due to human activities but with concentrations remaining at trace levels (i.e., up to the microgram per liter range)" [38]. Although found at very low concentrations 
in aqueous solutions (from $\mathrm{pg} / \mathrm{L}$ to $\mu \mathrm{g} / \mathrm{L}$ ), EMPs can induce severe toxicological effects, usually after long-term exposure.

EPs can be categorized considering their physico-chemical properties [4] as: organics with polarity (e.g., pharmaceuticals, industrial chemicals, pesticides); contaminating particles (e.g., nanoparticles and microplastics).

Once in the environment, sewage, surface water or treated effluents, EPs are more polar, acidic and alkaline than natural chemicals, making them dangerous at some concentrations. Lots of EPs are hydrophobic being dynamic through food chain, so they can accumulate in the lipid-rich tissues or can influence the endocrine system of animals and humans by direct or indirect exposure [3,39,40] (Figure 2).

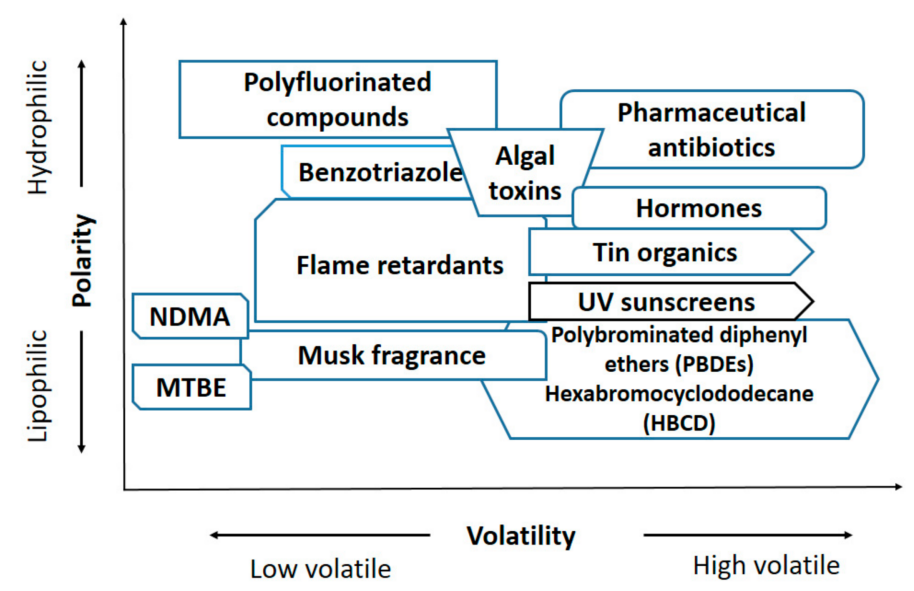

Figure 2. Emerging pollutants volatility and polarity (adapted upon [41]).

A category of organic compounds that was recently included in the list of EPs is represented by ultraviolet radiation screening compounds or organic UV filters [42]. Although they can be considered as personal care products (PCPs), these compounds need special attention, since the increasing production and use of organic UV filters has made them a new category of environmental pollutants. These compounds are used extensively in the composition of sunscreen products, since they possess the ability to absorb solar radiation due to their large molar absorption coefficient in the UVA $(320-400 \mathrm{~nm})$ and UVB ranges $(280-320 \mathrm{~nm})$ [43]. Therefore, UV filters can protect consumers from the harmful effects of solar radiation and also increase the light stability of personal care products such as skin creams, hair sprays, cosmetics, hair dyes, shampoos, body lotions, etc. Their widespread use and monitoring have shown that these compounds can accumulate in the human body (being extremely lipophilic), in the environmental compartments and ecosystems [44,45]. Moreover, some preliminary animal studies have shown that some UV filters are endocrine disruptors [46,47]. Other risks associated with their presence in the environment are very little known.

UV filters enter surface water owing to the large numbers of swimmers and sunbathers during recreational activities. The beaches are the most exposed, and water in gulfs or seas can contain different UV filters from solar protection creams, such as ethylhexyl methoxycinnamate, EHMC; octocrylene, OC; butyl methoxydibenzoylmethane, BM-DBM; benzophenone-3, BP3, etc., and their monitoring anticipates hundred kilograms per year as potential of water contamination with UV filters [45]. They were identified in rivers, lakes, sea water, groundwater, sediments and biota. However, the major pollution source is represented by the effluents from the wastewater treatment plants (WWTPs). As in the case of the other categories of EPs, WWTPs are not very effective in the removal of organic UV filters. Ramos et al. provided an extensive overview on occurrence and fate of a large category of UV filters in different wastewater treatment plants [48].

If the concentration of these compounds in the aquatic environment reaches relevant levels, the quality of wastewater effluents is significantly reduced and the reuse of treated 
wastewater becomes limited [2,15,49]. For this reason, their occurrence and negative impacts on the aquatic environment and human health need to be fully investigated. Analysis of these compounds in complex matrices such as wastewater requires sensitive and very specific methods, as, in fact, in the case of other EPs (such as liquid chromatography coupled with tandem mass spectrometry (LC-MS/MS)).

Presently, the European legislation provided the maximum allowed concentration for each UV filter in cosmetic products (Regulation no. 1223/2009 of the European Parliament and of the Council of 30 November 2009 on cosmetic products, [50]). A number of 27 UV filters are allowed in the EU, in concentrations between $2-15 \%$. Some organic UV filters can be converted in transformation products (TP) as a result of photodegradation under the action of solar radiation or by biodegradation in the environment, and for these reasons they are not detected during monitoring [51]. As in the case of the other categories of EPs, further experimental studies should be elaborated on the fate of UV filters mixtures in the environment.

Additionally, European legislation includes other provisions on emerging pollutants, such as: the REACH (Regulation (EC) No 1907/2006 of the European Parliament and of the Council of 18 December 2006 concerning the Registration, Evaluation, Authorisation and Restriction of Chemicals) [52]; regulation laying down the procedures for the authorization and supervision of medicinal products for human and veterinary use (Regulation of the European Parliament and of the Council amending Regulation (EC) no. 726/2004 laying down Community procedures for the authorization and supervision of medicinal products for human and veterinary use and establishing an European Medicines Agency) [53]. Under the Water Framework Directive (WFD) (Directive 2000/60/EC of the European Parliament and of the Council of 23 October 2000 establishing a framework for Community action in the field of water policy), EU member states monitor emerging substances that require this action as a consequence of the high frequency of occurrence and the potential risk to human health and the environment, on the basis of which a monitoring list of EPs is drawn up [8].

\section{Challenges of Emerging Pollutants}

\subsection{Sources of Pollution and Fate of EPs in the Environment}

Emerging pollutants, a wide range of compounds with some specific physico-chemical properties, raise numerous problems related to their removal from the environment. For example, the treatment of surface water and wastewater that contain emerging pollutants should take into account both the interactions between pollutants and those with various environmental conditions, such as seasons' succession, intensity of solar radiation, temperature, hydraulic resistances, etc. Lots of the emerging contaminants can be found in different areas where they have never been used, because of their properties, such as persistence during long distance transport and bioaccumulation [3,54-56].

Emerging pollutants can occur in the environment from various point or diffuse sources, and then reach the soil, atmosphere or water bodies through several ways or mechanisms that depend largely on EPs properties (polarity, volatility, persistence, etc.) and the environmental compartments characteristics [4]. EPs and some of their metabolites are released into the environment over several routes from industry, households, hospitals, lands, etc., (Figure 3 ) and enter surface and ground waters [14,57]. 


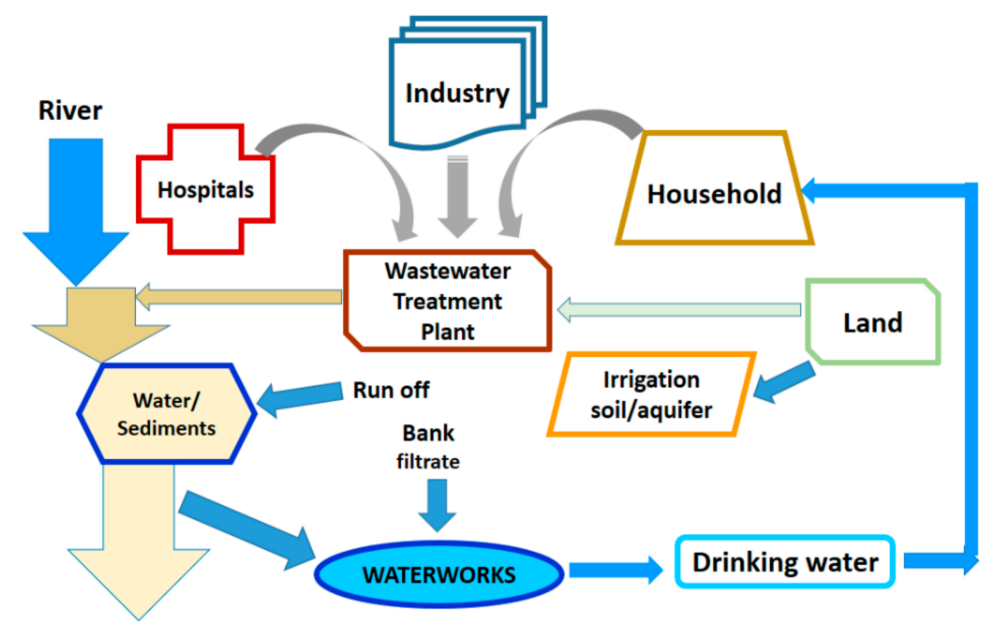

Figure 3. Origins of emerging pollutants and their routes in the environment (adapted upon https: / / www.norman-network.net/sites / default/files / files/Events / 2006-2008/2006Jun1920-Stresa-EmEnvPollutants-KeyIssuesChallenges/03-sess1_ternes.pdf).

EPs can become easily pollutants of river ecosystems where insufficient treated effluents from wastewater treatment plants (WWTP) are discharged (Figure 4). They can (bio)accumulate in sediments and river flora and fauna due to their persistence, since their biodegradation, chemical degradation and photodegradation (in absence of light) can occur at very small rates. Hence, their disappearance from water environment is almost negligible $[58,59]$. Although, certain microbial populations are able to struggle the biocide effect of EPs and feasibly alter them, increasing their degradation rate. There are few studies investigating the natural biodegradation of EPs such as hormones, some detergents or pharmaceuticals. Usually, these studies are performed in the laboratory, but it is not certain that the experimental systems replicate well the real environmental condition, while the implementation of these results at large-scale is not sufficiently clarified yet $[3,4,59]$. Therefore, the development of studies and research for finding and exploiting microbial populations tailored for different categories of EPs or even targeted for certain compounds is a task with great perspectives for researchers.

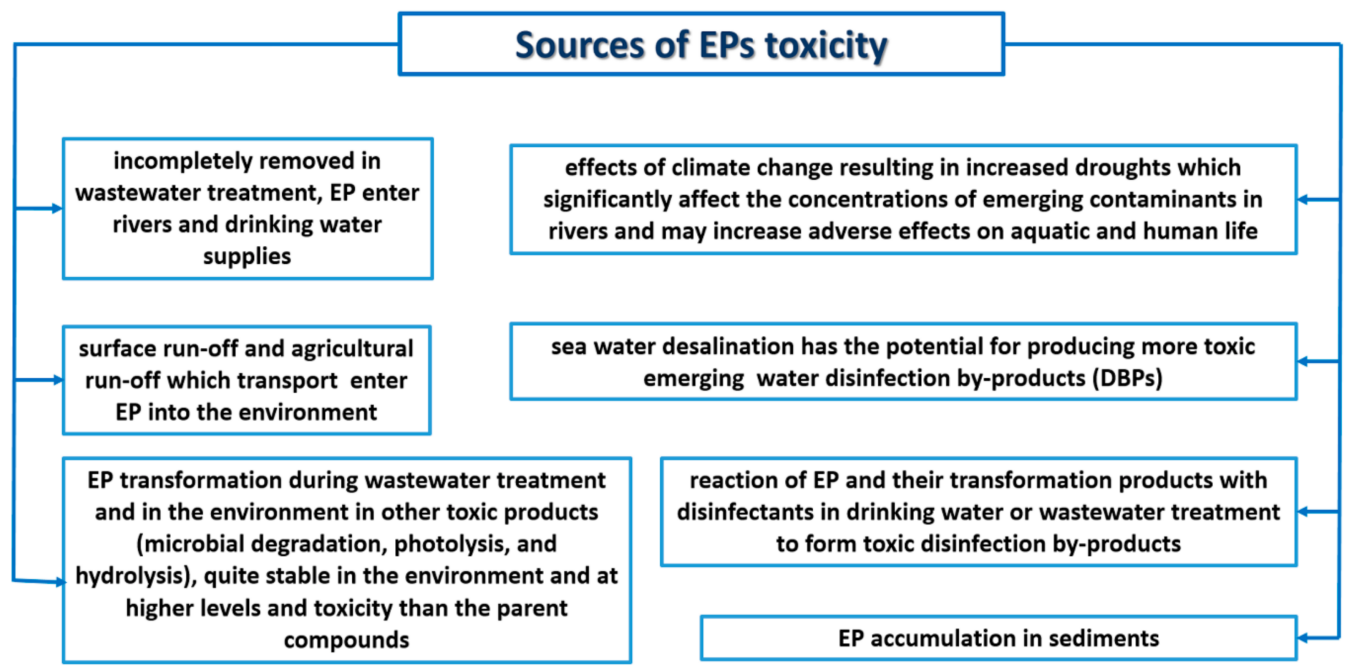

Figure 4. Incidence of emerging pollutants' (EPs) toxicity from various sources of pollution (hazards), which can generate environmental and human threats/consequences. 


\subsection{Environmental and Health Risks Associated with Emerging Pollutants}

The incidence of environmental and human health risks related to EPs is due to their toxicity. EPs are considered highly toxic, since nanogram per liter (ng/L) concentrations can exhibit relative effects to both humans and aquatic organisms, such as hormonal interference in fishes, genotoxicity, carcinogenicity in lab animals, endocrine disruption and immune toxicity $[60,61]$. It is not known and/or it is difficult to estimate the long-term impacts of the majority of EPs on the environment and human health and this is still a concern, while the awareness on their behavior and hazard/ecological risks is really insufficient. Literature recommends the application of specific tools for assessing the toxicity effects of emerging pollutants: environmental risk assessment (ERA), quantitative analysis of the structure-activity relationship (QSAR), the relationship between physicochemical properties and environmental behavior and fate (PPEF), assisted by software tools $[4,29,62-64]$.

The existing studies on the risks caused by emerging pollutants in the environment and, in particular, in water have taken into account their toxicity on aquatic flora and fauna (fish, algae, daphnia) but have also focused on the risks to human health, especially in water recovery and reuse systems (Table 2). However, given the low concentrations of these pollutants in liquid flows, data collection on the toxicity parameters and human exposure are, thus, real scientific challenges $[65,66]$.

In this context, guidelines have been developed by the United States Environmental Protection Agency [67] and the World Health Organization (WHO), which provides methods for assessing the risk of EPs to human health and ascertaining factors of exposure to various chemicals. In the European Union, protocols and methodologies have been developed for the analysis of risks generated by chemicals, starting from 1980 (for "new chemicals"), then, at the beginning of the 1990s, pharmaceutical products were considered [54]. One of the most important developments regarding the registration and evaluation of the authorization of chemicals is represented by the REACH regulation [52].

Literature on ecological and human health risks has focused, as a priority, on classes of contaminants in wastewater and surface water [68]. Additionally, some studies addressed the EPs accumulation in sediments, which are usually seen as a sink for EPs and toxicity $[69,70]$. Moreover, sediments can become a source of contamination with EPs for aquatic flora and fauna if the particles forming the sediments are remobilized and suspended in the moving liquid flow (e.g., during floods) (Figure 4). EPs associated with solid particles can become potentially bioavailable to benthic organisms, and if the level of bioaccumulation is high enough, they can generate acute and chronic exposure and spread to higher trophic levels [71-73].

In river water, EPs can undergo possible transformations into less toxic, but also, even more toxic products can be adsorbed on sediments where they accumulate or are transported to other water bodies, where sensitive or protected flora and fauna can exist, or in groundwater that often serves as a source of drinking water [72]. There, EPs will manifest their toxic effects, depending on their category and mixtures (Table 3). If EPs are in mixtures, the toxic effects can cumulate and generate synergistic or antagonistic interactions, leading to the so-called cocktail effect, so that the difficulty of risk analysis increases $[4,16,62]$. In this context, the precautionary principle needs to be applied consistently to ensure a clean and healthy environment for future generations, which is why further studies on the risks induced by EPs (as a result of their specific environmental behavior, toxicity and impacts on the environment and human health) become essential. 
Table 2. Toxicities of the drugs and pharmaceuticals residues in aquatic organisms and plants *.

\begin{tabular}{|c|c|c|c|}
\hline Therapeutic Group & Compounds & Taxonomic Group & $\begin{array}{c}\text { Long-Term } \\
\text { Exposure }(\mathrm{mg} / \mathrm{L})\end{array}$ \\
\hline Anti-bacterial & Trimethoprim & Plant (duckweed) & $>1.0(\mathrm{EC} 10)$ \\
\hline Anti-bacterial (aminoglycoside) & Neomycin & Plant (duckweed) & $>1.0(\mathrm{EC} 10)$ \\
\hline (Aminoglycoside) anti-bacterial & Streptomycin & Plant (duckweed) & $>1.0(\mathrm{EC} 10)$ \\
\hline Anti-bacterial & Cephalexin & Plant (duckweed) & $>1.0(\mathrm{EC} 10)$ \\
\hline \multirow{2}{*}{ Anti-bacterial } & Ciprofloxacin & Plant (duckweed) & $0.106(\mathrm{EC} 10)$ \\
\hline & Norfloxacin & Plant (duckweed) & $0.206(\mathrm{EC} 10)$ \\
\hline Anti-bacterial (macrolide antibiotic) & Erythromycin & Plant (duckweed) & $>1.0(\mathrm{EC} 10)$ \\
\hline \multirow{2}{*}{ Anti-bacterial (macrolide antibiotic) } & Lincomycin & Plant (duckweed) & $>1.0(\mathrm{EC} 10)$ \\
\hline & Roxithromycin & Plant (duckweed) & $>1.0(\mathrm{EC} 10)$ \\
\hline \multirow[t]{3}{*}{ Anti-bacterial (macrolide antibiotic) } & Tylosin & & $>1.0(\mathrm{EC} 10)$ \\
\hline & Sulfadimethoxine & Plant (duckweed) (duckweed) & $>0.044(\mathrm{EC} 10)$ \\
\hline & Sulfamethazine & Plant (duckweed) & $>1.0(\mathrm{EC} 10)$ \\
\hline \multirow[t]{6}{*}{ Anti-bacterial (sulfonamide) } & Plant & Plant (duckweed) & 0.011 (EC10) \\
\hline & Plant & 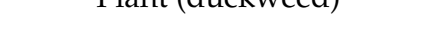 & $2.33($ EC50) \\
\hline & Sulfamethoxazole & & $2.33(\mathrm{EC} 50)$ \\
\hline & Sulfachlorpyridazine & & \\
\hline & Chlortetracycline & Plant (duckweed) & $0.036(\mathrm{EC} 10)$ \\
\hline & Doxycycline & Plant (duckweed) & 0.055 (EC10) \\
\hline \multirow[t]{3}{*}{ Anti-bacterial (tetracycline) } & Oxytetracycline & Plant (duckweed) & 0.788 (EC10) \\
\hline & & Plant (duckweed) & $4.92(\mathrm{EC} 50)$ \\
\hline & Tetracycline & Plant (duckweed) & $0.23(\mathrm{EC} 10)$ \\
\hline Anti-depressant & & Plant (duckweed) & $>1.0(\mathrm{EC} 10)$ \\
\hline Fluvoxetine & Sertraline & Plant (duckweed) & $>1.0(\mathrm{EC} 10)$ \\
\hline \multirow{3}{*}{ Anti-diabetic (biguanide) } & \multirow{3}{*}{ Metformin } & Alga (green) & $>320.0($ EC50) \\
\hline & & Plant (duckweed) & $110.0(\mathrm{EC} 50)$ \\
\hline & & Alga (green) & $74.0(\mathrm{EC} 50)$ \\
\hline \multirow[t]{2}{*}{ Anti-epileptic } & \multirow[t]{2}{*}{ Carbamazepine } & Plant (duckweed) & $>1.0(\mathrm{EC} 10)$ \\
\hline & & Plant (duckweed) & 25.5 (EC50) \\
\hline \multirow[t]{2}{*}{ Anti-hyperlipidemic } & \multirow[t]{2}{*}{ Atorvastatin } & Plant (duckweed) & 0.085 (EC10) \\
\hline & & Alga & $5.4(\mathrm{EC} 10)$ \\
\hline \multirow[t]{2}{*}{ Anti-hyperlipoproteinemic } & \multirow[t]{2}{*}{ Clofibric acid } & Alga (green) & $115.0($ EC50) \\
\hline & & Plant (duckweed) & $12.5(\mathrm{EC} 50)$ \\
\hline \multirow{2}{*}{ Anti-hypertensive } & \multirow{2}{*}{ Captropril } & Alga (green) & $168.0($ EC50) \\
\hline & & Plant (duckweed) & $25.0(\mathrm{EC} 50)$ \\
\hline \multirow{2}{*}{ Anti-protozoal } & \multirow{2}{*}{ Metronidazole } & Alga (green) & 2.03 (EC10) \\
\hline & & Alga (green) & $19.0(\mathrm{EC} 10)$ \\
\hline \multirow{2}{*}{ Bone resorption inhibitor } & \multirow[b]{2}{*}{ Tiludronate } & Alga (cyanobacteria) & 13.3 (EC50) \\
\hline & & Alga (green) & 36.6 (EC50) \\
\hline \multirow[t]{4}{*}{ Nicotine metabolite } & Cotinine & Plant (duckweed) & $>1.0(\mathrm{EC} 10)$ \\
\hline & Acetaminophen (paracetamol) & Plant (duckweed) & $>1.0(\mathrm{EC} 10)$ \\
\hline & & Alga (green) & $72.0(\mathrm{EC} 50)$ \\
\hline & Diclofenac & Plant (duckweed) & 7.5 (EC50) \\
\hline \multirow{5}{*}{ Non-steroid anti-inflammatory drug } & Tbuprofen & Alga (green) & 315.0 (EC50) \\
\hline & Ibuprołen & Plant (duckweed) & $>1.0(\mathrm{EC} 10)$ \\
\hline & & Plant (duckweed) & $22.0(\mathrm{EC} 50)$ \\
\hline & Naproxen & Alga (green) & $>320.0$ (EC50) \\
\hline & & Plant (duckweed) & $24.2(\mathrm{EC} 50)$ \\
\hline Estrogen & Ethinylestradiol & Alga & $0.054(\mathrm{EC} 10)$ \\
\hline & Metoprolol & Alga (green) & $7.3(\mathrm{EC} 50)$ \\
\hline B-Adreneroic recentor blocker & Metoprolol & Plant (duckweed) & $>320.0(\mathrm{EC} 50)$ \\
\hline \$-Adrenergic receptor blocker & & Alga (green) & $5.8($ EC50) \\
\hline & Propranolol & Plant (duckweed) & $114.0(\mathrm{EC} 50)$ \\
\hline
\end{tabular}

* reproduced from [29] with the permission of Elsevier, license 4890980598709, from 16 August 2020. 
Table 3. The toxic effects of typical EPs in the environment [62] *.

\begin{tabular}{|c|c|c|}
\hline Emerging Pollutant & Ecology Effect & Human Health Effect \\
\hline Engineered nanoparticles & $\begin{array}{l}\text { Toxicity in plants, fish, earthworm, bacteria } \\
\text { (growth, mortality, reproduction, } \\
\text { gene expression) }\end{array}$ & $\begin{array}{l}\text { Cytotoxicity, oxidative stress, inflammatory } \\
\text { effects, in lungs, genotoxicity, carcinogenic } \\
\text { effects, granulomas, thickening of alveolar wall } \\
\text { and augmented intestinal collagen staining }\end{array}$ \\
\hline Endocrine disruptors & Toxic to wildlife, human & $\begin{array}{c}\text { Alter reproductively relevant, sexually } \\
\text { dimorphic neuroendocrine system, alter } \\
\text { endogenous steroid levels, etc., diabetes, } \\
\text { problems in the cardiovascular system, abnormal } \\
\text { neural behaviors and linked to obesity }\end{array}$ \\
\hline Ionic liquids & $\begin{array}{l}\text { Inhibitory effects on a variety of bacteria and } \\
\text { fungi, influencing the growth rate of algae, } \\
\text { toxic to invertebrates, fish and frogs }\end{array}$ & Adverse effects on neuronal process, cytotoxicity \\
\hline Perfluorinated compounds & Bioaccumulation in fish and fishery products & $\begin{array}{l}\text { Accumulate primarily in the serum, kidney and } \\
\text { liver, potentially adverse effects on } \\
\text { developmental, reproductive systems and other } \\
\text { damaging outcomes }\end{array}$ \\
\hline
\end{tabular}

* reproduced from [62] with the permission of Elsevier, license 4912101420021, from 18 September 2020.

Often, the origin of EPs and the risks generated by them are difficult to detect, as long as they can originate from diffuse sources of pollution such as sewer leaks and discharges, storm water runoff in urban areas and on agricultural land, etc. (Figures 3-5). To estimate the risks generated by EPs from various sources towards various receptors, it is necessary to identify them and determine the acute and chronic doses and exposures. The information needed for risk estimation and analysis is obtained in research laboratories developing studies in environmental chemistry, toxicology and ecotoxicology that can generate original data and complete sets of tests according to existing regulations. These steps can facilitate the identification and characterization of sources (hazards), pathways (transport and fate of EPs), receptors and consequences, including human exposure (pollutant linkage) [62,74].

Currently, the environmental risk assessment (ERA) is performed by calculating the value of the ratio between the predicted environmental concentration (PEC) and the predicted no effect concentration $(P N E C)$ for a certain single substance $[75,76]$. Somewhat recently, the development of pharmacokinetic models based on physiological biotransformations in the entities affected by EPs (PBPK) allowed the description of EPs intake, distribution, metabolism and excretion [4,77]. However, in most cases, addressing the relationship of some EPs with the environment and the associated risk, the pathway from source to receptor is difficult to clarify, especially for new substances, because this pathway depends on many factors related to the substances themselves, the source (hazard), environmental conditions and potential treatments to which EPs are subjected (Figure 5). 


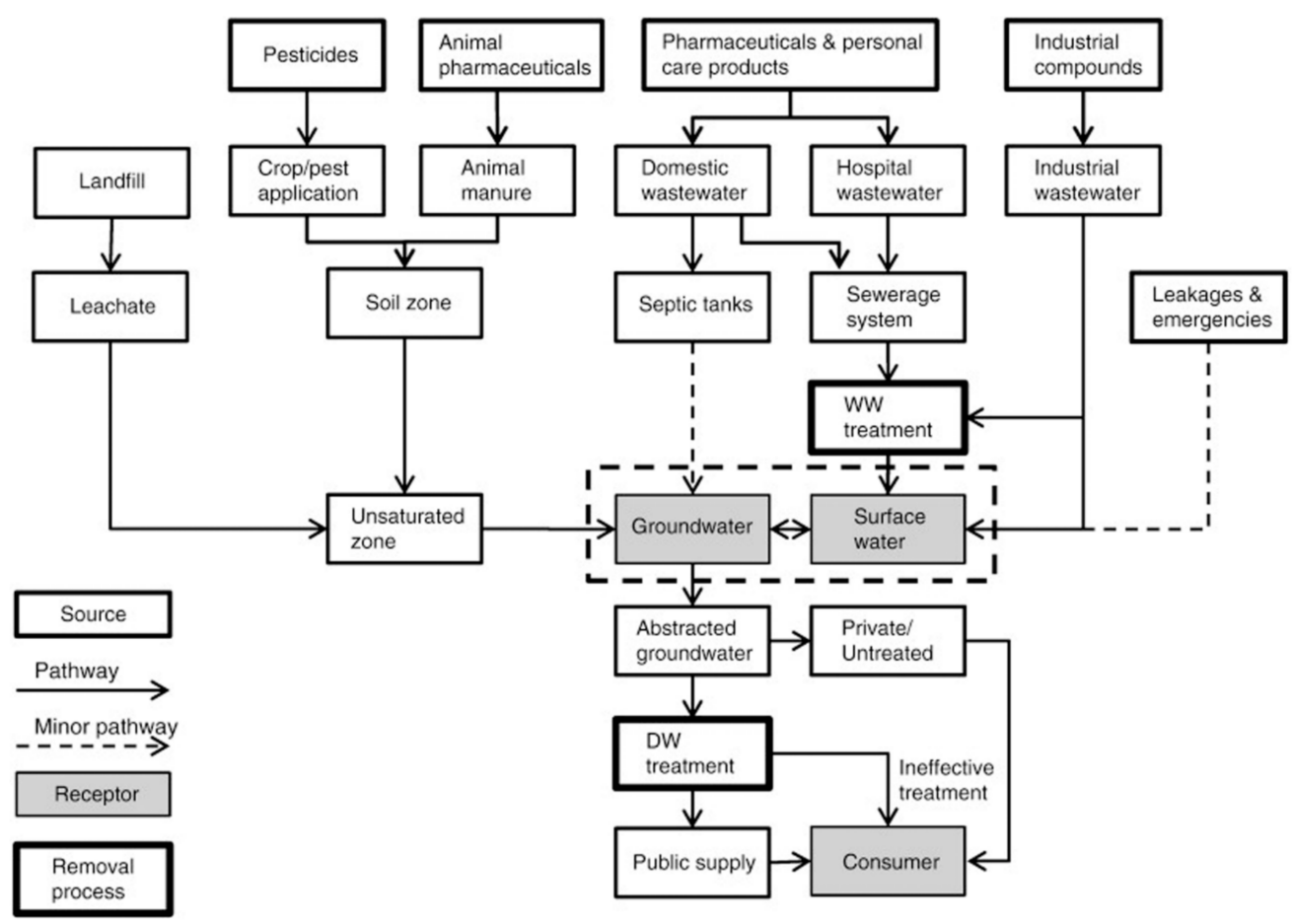

Figure 5. Sources (bold) and pathways for emerging contaminants to reach various receptors (grey) [73]. (Reproduced from [73] with Elsevier permission, license 4912431334481, from 19 September 2020).

Solving these problems as quickly as possible would facilitate the best decisions for risks management. Besides, the estimation and analysis of risks generated by mixtures of EPs impose new strategies, which should reproduce the reality as accurately as possible, because, if only one substance from the mixture is taken into analysis or each substance separately, the toxicity of the mixture can be underestimated or overestimated [76]. In literature, two types of problems are addressed regarding this matter [78]:

- $\quad$ Evaluation of mixture toxicity, when the results are valid only for that mixture and cannot be extrapolated to other exposure scenarios;

- Evaluation taking into account the components of the mixture, when the results can be interpreted in two ways: by cumulating the toxicities of the components or considering the independent action of each component of the mixture leading to a common toxicological effect.

However, these two approaches cannot describe the real effects of EPs mixtures, some studies showing that estimating toxicity by testing mixtures can lead to a higher toxicity than the actual value, while individual estimations can result in a lower toxicity than the actual one [76,78].

Risk assessment and analysis are relevant issues for EPs research, since they can allow the management of pollutants in a "risk-based" approach, by providing the support for decisions making on the appropriate remediation options, both in terms of risk reduction and cost effectiveness and efficiency, in an integrated way (Figure 6). Integrated risk assessment facilitates risk communication to stakeholders for analysis and making decisions regarding risk mitigation $[57,62,71]$. 


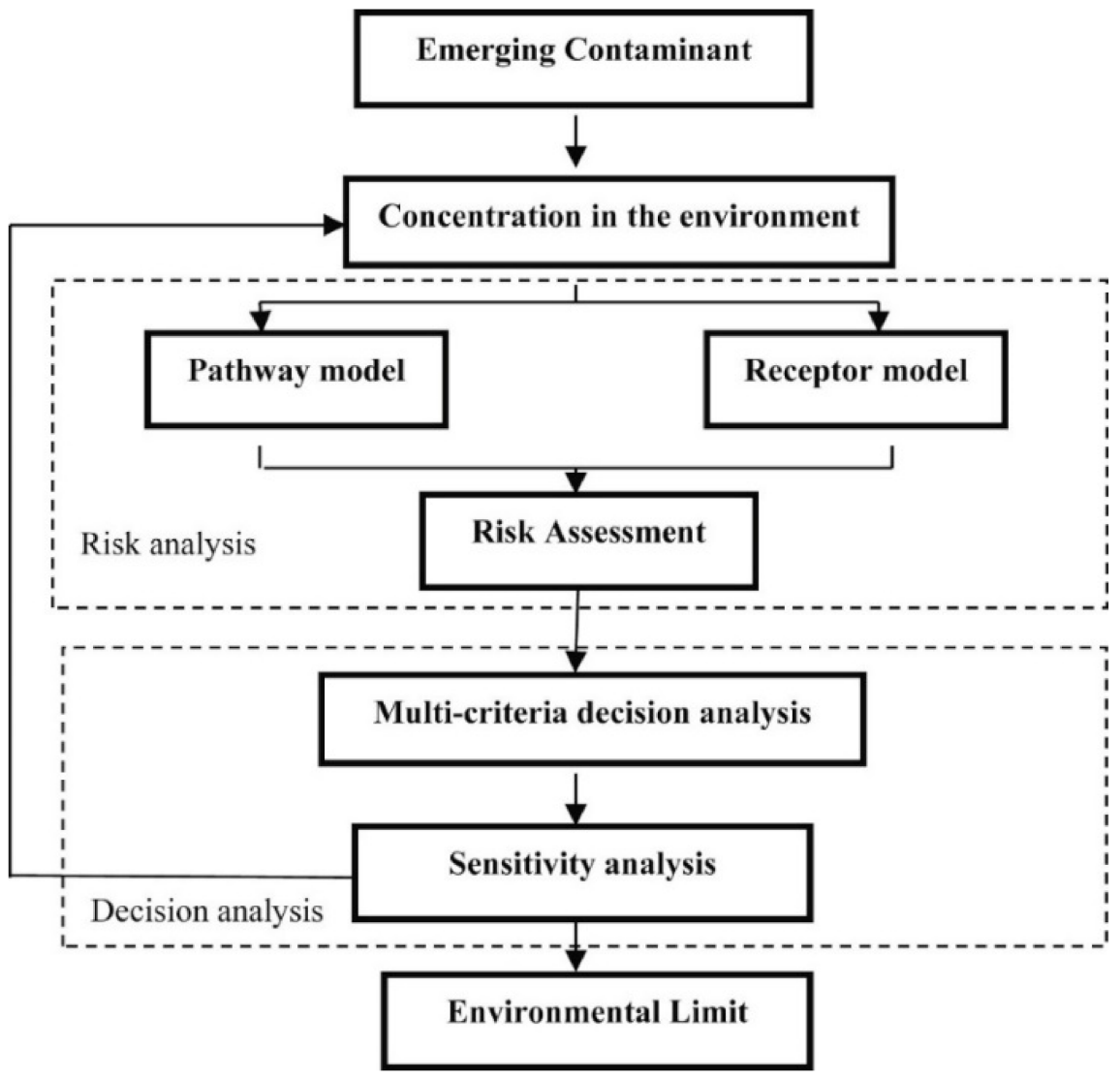

Figure 6. Risk-based decision analysis [62] (reproduced from [62] with Elsevier permission, license 4912101420021, from 18 September 2020).

\subsection{Short Overview on the Assessment of Risks Generated by Emerging Pollutants}

Ecological and human health risks of EPs are assessed in view of generating decisionmaking support to ensure the protection of ecological systems, in particular the aquatic environment, as well as human health. The subjects of human health risk assessment are individuals who may come into direct or indirect contact with toxic pollutants, either through the consumption of drinking water or the intake of contaminated food or vegetable products irrigated with reclaimed water insufficiently purified. At the level of the European Commission, it is emphasized that, if chemical exposure is assessed, it is necessary to take into account the cumulative effect of previous emissions, which can generate residual or background concentrations [79].

One of the most widely applied approach for assessing the ecological risk of detected EPs is the risk quotient $(R Q)$ method. $R Q$ is calculated according to Equation $(1)[80,81]$ :

$$
R Q=\frac{M E C}{P N E C}
$$

where $M E C$ represents the measured environmental concentration; $P N E C$ is the predicted no-effect concentration.

" $R Q$ s essentially constitute an index for quantification of the environmental risk of chemicals and involve comparison of the environmental concentrations of pollutants with the concentrations that should ensure an absence of adverse effects on target organisms, based on empirical data" [82,83].

When the risk analysis is performed for the aquatic environment emphasized, it is imperative to evaluate the concentrations detected in the environment and the chronic toxicity of EPs for aquatic organisms, in view of $R Q$ determination [84]. PNEC results by dividing the value of acute (short-term) or chronic (long-term) toxicity by an assessment 
factor (AF) [79]. Acute toxicity can be considered as the median lethal concentration (LC50) or mean effective concentration (EC50), in which case AF $=1000$. Chronic toxicity is given by no observable effect concentration (NOEC), in which case AF can be 100, 50, 10 depending on the trophic levels $[85,86]$. In this context, the risk level can be (i) low, when $R Q \leq 0.1$; (ii) medium, when $0.1<R Q<1$; (iii) high, when $R Q \geq 1$ [87].

$R Q$ calculated with Equation (1) refers to the toxicity of EPs based on measured environmental concentrations, but does not take into account variations in concentrations over time that would expose aquatic organisms to levels of toxicity above the tolerability limits, especially in case of compounds with long-term presence in water bodies. In this circumstance, there is the problem of differentiated risk analysis for frequently detected EPs and, respectively, for occasionally detected EPs, i.e., the consideration of a frequency factor in the calculation of $R Q$. In this context, Zhou et al. [84] proposed a new risk quotient $(R Q f)$ based on the average value of $R Q$ and the frequency of $M E C$ s exceeding $P N E C$ and applied in the assessment of the potential risks posed by the detected substances. The RQf value can be calculated according to Equations (2) and (3):

$$
\begin{gathered}
R Q f=R Q \times F=\frac{M E C}{P N E C} \times F \\
F=\frac{N O_{1}}{N O_{2}}
\end{gathered}
$$

where $R Q f$ is the frequency-based risk quotient, in fact, an optimized risk quotient resulted after the frequency of $M E C$, which exceed $P N E C$ was considered; $F$ is the frequency of $M E C$ s exceeding $P N E C ; N O_{1}$ represents the number of samples with concentrations higher than PNECs; $\mathrm{NO}_{2}$ represents the total number of samples. $R Q f$ was classified in 5 groups as shown in Table 4.

Table 4. Characterization of risks based on the frequency-based risk quotient.

\begin{tabular}{cc}
\hline Range of $R Q f$ Values & Risk Characterization \\
\hline$R Q f \geq 1$ & High environmental risk \\
$1>R Q f \geq 0.1$ & Moderate environmental risk \\
$0.1>R Q f \geq 0.01$ & Small-scale adverse effect (endurable risk) \\
$0.01>R Q f>0$ & Limited (negligible risk) \\
$R Q f=0$ & No risk (safe) \\
\hline
\end{tabular}

Risks assessment to human health associated with EPs is based on the responses of some biological species to the dose-response relationship for a certain range of EPs concentrations. Although their effects on humans have not been too much explored, the adverse effects on human health are quantified mainly based on models. These models need to be validated in order to quantitatively estimate the ability of EPs to produce major changes to human health and what types of risks are significant [88]. The non-carcinogenic risk due to EPs ingestion can be assessed using the hazard index (HI), calculated for different exposure pathways (inhalation, ingestion, dermal contact, etc.) (Equation (4)) [86]:

$$
H I_{\text {ingestion }}=\frac{C D I_{\text {ingestion }}}{R f D}
$$

where CDI represents the chronic daily intake of the EPs by ingestion $(\mathrm{mg} /(\mathrm{kg} \cdot$ day $))$, and $R f D$ is the reference dose for the EPs ( $\mathrm{mg} /(\mathrm{kg} \cdot$ day $))$.

For $H I>1$, adverse health effects can occur, while for $H I<1$, the effects are insignificant. The CDI value can be estimated according to Equation (5) [80]:

$$
C D I=\frac{C \times I R \times E F \times E D}{B W \times A T}
$$


where $C$ is the concentration of EPs in water; $I R$ means the rate of polluted water intake (determined as $1.41 \mathrm{~L} /$ day for an adult and $0.87 \mathrm{~L} /$ day for a child); $E F$ is the frequency of exposure (365 days/year); $E D$ is the exposure period (70 years for an adult, 6 years for a child); $B W$ is body weight (70 kg for an adult, $20 \mathrm{~kg}$ for a child); $A T$ is the average lifespan (25,550 days for an adult, 2190 days for a child (according to [79]).

RfD can be calculated according to Equation (6) [80]:

$$
R f D=L D_{50} \times 4 \times 10^{-5}
$$

In most cases, human exposure does not occur in relation to only one pollutant, but mixtures of chemicals are involved. For this reason, researchers have developed methods for assessing the risks to human health associated with exposure to various sets of pollutants.

The total potential non-carcinogenic risks produced by different paths can be assessed by the cumulated hazard index $\left(H I_{\text {cum }}\right)$, as expressed by Equation (7) [19]:

$$
H I_{\text {cum }}=\sum\left(H I_{\text {ingestion }}+H I_{\text {derm })}\right)
$$

Similarly, for $H I_{\text {cum }}>1$, there are adverse effects on human health [19].

Fabrega et al. [89] have calculated the Integrated Risk Index of Chemical Aquatic Pollution (IRICAP) (Equation (8)):

$$
I R I C A P=\frac{\sum(\text { hazardindex } \times \text { chemicalconcentration })}{\text { numberofchemicals }}
$$

To calculate IRICAP, the hazard index of each individual compound was multiplied by the normalized water concentration at each sampling point, and then being summed and the final amount divided by the number of pollutants. Concentrations are normalized for each chemical (according to Equation (9)), to avoid any overestimation for each chemical.

$$
C_{\text {norm }}=\frac{C_{i}-C_{\min }}{C_{\max }-C_{\min }}
$$

In order to mitigate the risks generated by EPs in the environment and for human health, various management options can be applied when specific analyses reveal that an emerging pollutant can be considered as producing unacceptable risks [90]. First, it is essential to prevent risks by applying sustainable, ecological industrial practices and technologies for the synthesis of environmentally friendly products, mostly biodegradable. On the other hand, it is necessary to develop efficient wastewater treatment technologies able to reduce the amounts of EPs that can reach natural water bodies.

\section{Removal of EPs from the Environment as Solution for Risks Mitigation}

As a result of the continuous rising of awareness on the occurrence and threatens produced by EPs in the environment, their treatment and removal have become increasingly challenging concerns for researchers and practitioners $[4,74,91]$. Due to some of their properties mentioned above, EPs that commonly occur in industrial and municipal wastewater treatment plants are difficult to be removed by applying conventional treatment technologies [21,92]. Therefore, the application of efficient treatment processes is imperative to favor the discharge of effluents with low impact on aquatic systems and the environment in general.

\subsection{Short Analysis of Processes Applied for EPs' Removal}

Research has generated progress for EPs removal to overcome the problems of traditional treatment plants. This would ensure an efficient management of effluents developed to comply with the regulations in force on the discharge of treated effluents. In this context, efficient methods for advanced treatment of effluents polluted with EPs are developed, 
which include physico-chemical and biological processes (sand and media filtration; chlorination; advanced oxidation processes, AOPs; adsorption using granular activated carbon, zeolite or other clay materials; hydrolysis processes; constructed wetland (CW); membrane bioreactors, phytoremediation, biosorption), as illustrated in Figure 7 [93-95].

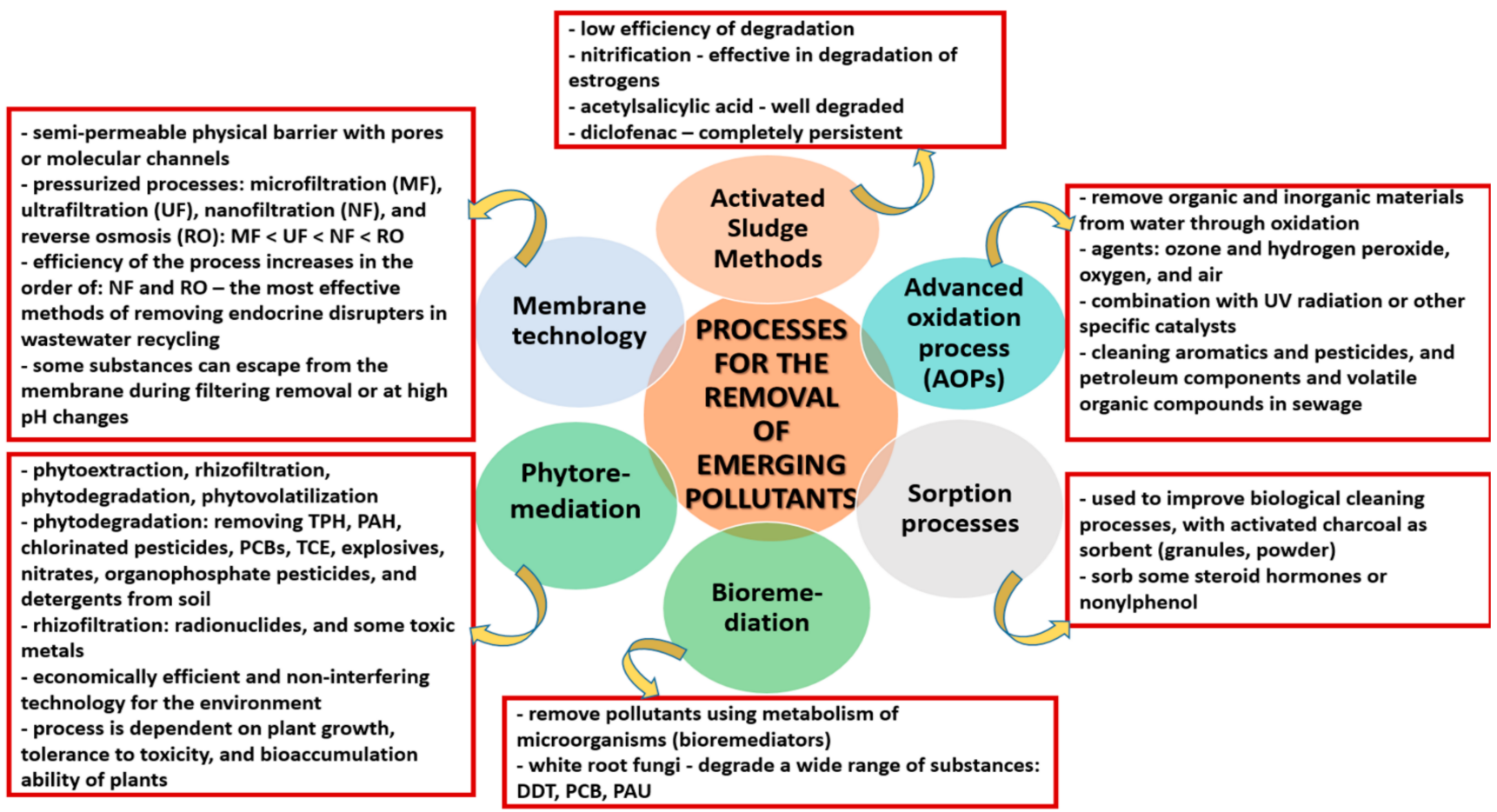

Figure 7. Physico-chemical and biological processes applied for the removal of emerging pollutants from the environment (developed mainly based on information from [93-95]).

The application of activated sludge process to remove emerging pollutants is usually recommended to reduce high organic loads, but it is not suitable for removing EPs, especially at very low concentrations or traces of pollutants [96]. In addition to the low EC removal efficiency, the traditional activated sludge process is associated with the production of a very large amount of activated sludge, which is treated as waste [97].

EPs are currently removed from water by adsorption or oxidation processes or a combination of biological and advanced treatment processes [98,99]. Although conventional and advanced oxidation processes proved to be effective, they have the disadvantage that can lead to the formation of intermediates, which are often unidentifiable or difficult to identify and can sometimes be more toxic than the initial compounds. From this point of view, adsorption is beneficial, since it does not generate unwanted by-products, and the loaded adsorbed can be then properly treaded. Emerging pollutants with high polarity, such as a large part of pharmaceuticals, can be removed by biological degradation and mineralization achieved by specific microorganisms, respectively [14,100]. Table 5 describes certain advantages and challenges of some processes applied to remove EPs. 
Table 5. Advantages and challenges of different technologies in the removal of emerging pollutants [100] *.

\begin{tabular}{|c|c|c|}
\hline Treatment Process & Advantages & Challenges \\
\hline \multicolumn{3}{|l|}{ Conventional } \\
\hline \multirow{3}{*}{ Biological activated carbon } & A wide range of EPs removal from wastewater & Relatively high cost in operation and maintenance \\
\hline & Removal of residual disinfection/oxidation products & Regeneration and disposal of high sludge amounts \\
\hline & Not generating toxic active products & Processing of sludge can increase total cost by $50-60 \%$ \\
\hline \multirow{2}{*}{ Microalgae reactor } & \multirow{2}{*}{$\begin{array}{l}\text { Resource recovery of algal biomass, used as fertilizer } \\
\text { High quality effluent and no acute toxicity risk } \\
\text { associated with EPs }\end{array}$} & Removal efficiencies affected by cold season \\
\hline & & EPs cannot be degraded properly \\
\hline \multirow{3}{*}{ Activated sludge } & Lower capital and operational costs than AOPs & Low efficiencies for pharmaceuticals and beta blockers \\
\hline & \multirow{2}{*}{ More environmentally friendly than chlorination } & Large amount of sludge containing EPs \\
\hline & & $\begin{array}{l}\text { Unsuitable where Chemical Oxygen Demand (COD) } \\
\text { levels are higher than } 4000 \mathrm{mgL}^{-1}\end{array}$ \\
\hline
\end{tabular}

$\begin{array}{ll}\text { Non-conventional } & \begin{array}{l}\text { Low energy consumption and low operational and } \\ \text { maintenance costs }\end{array}\end{array}$

High performance on removal of estrogens, pathogens

Effective for the removal of biorecalcitrant EPs

\section{MBR}

Small footprint

\section{Chemical process \\ Coagulation}

Ozonation

AOPs

Fenton and photo-Fenton

Photocatalysis $\left(\mathrm{TiO}_{2}\right)$
Reduced turbidity arising from suspended inorganic and organic particles

Increased sedimentation rate through suspended solid particles formation

Strong affinity to EPs in the presence of $\mathrm{H}_{2} \mathrm{O}_{2}$

Selective oxidant favoring disinfection and sterilization properties

Major ancillary effects on removal of EPs such as

pharmaceuticals, personal care products (PCPs and pesticides

Short degradation rate

Degradation and mineralization of EPs

Sunlight can be used by avoiding UV light

Degrading persistent organic compounds

High reaction rates upon using catalyst

Low price and chemical stability of $\mathrm{TiO}_{2}$ catalyst and easier recovery

\section{Physical process}

Micro- or ultra-filtration

Can remove EPs and pathogens

Useful for treating saline water and wastewater

Nanofiltration

treatment plants (WWTP) influents

Can remove dye stuff and pesticides

Useful for treating saline water and WWTP influents

Reverse osmosis
Can remove PCPs, endocrine disrupting compounds (EDCs) and pharmaceuticals
Clogging, solids entrapment and sediments formation

Biofilm growth, chemical precipitation and seasonal dependent

Needs large area of lands and long retention time High energy consumption and fouling control of heat and mass transfer

High aeration cost and roughness of membrane Pharmaceutical pollutants have low efficiencies

Ineffective micropollutants removal

Large amount of sludge

Introduction of coagulant slats in the aqueous phase High energy consumption, formation of oxidative by-products

Interference of radical scavengers

Energy consumption issues, operational and maintenance cost

Formation of toxic disinfection by-products Interference of radical scavengers

Decrease in $\mathrm{OH}^{*}$ forming chloro and sulfato-Fe(III) complexes or due to scavenge of $\mathrm{OH}^{*}$ forming $\mathrm{Cl}_{2}$ * and $\mathrm{SO}_{4}{ }^{*-}$ in the presence of chloride and sulphate ions

Difficult to treat large volume of wastewater Cost associated with artificial UV lamps and electricity Separation and reuse of photocatalytic particles from slurry suspension

Not fully effective in removing some EPs as pore sizes vary from 100 to 1000 times, larger than the micropollutants

High energy demand, membrane fouling and disposal issue

Limited application in pharmaceuticals removal

High energy demand, membrane fouling and disposal issue

Corrosive nature of finished water and lower pharmaceutical removal

${ }^{*}$ reproduced from [100] with Elsevier permission, license no. 4912441171076 of 19 September 2020.

\subsection{Progresses in Biological Treatments Applied for the Removal of Emerging Pollutants}

In recent decades, numerous studies have been dedicated to the development of innovative, sustainable technologies for the removal of EPs from wastewater, which is the most relevant source of pollution of the aquatic environment with EPs. Of these, biological processes have stimulated the interest of specialists for application to degrade some EPs, although certain extreme recalcitrant contaminants are still difficult to (bio)degrade or even 
impossible to remove. However, efficient innovative processes can be combined in hybrid systems, which can overcome the deficiencies in existing biological technologies.

\subsubsection{Removal of EPs in Constructed Wetlands}

Conventional wastewater treatment processes with activated sludge can be applied for wastewater treatment containing EPs, but in combination with advanced processes (tertiary treatment such as ozonization, photodegradation, biodegradation), which increase the efficiency of the treatment. The disadvantage of this combination of processes is that they are energy consuming and involve high costs, being disadvantageous especially for small communities. Constructed wetlands (CWs) can be a promising alternative as tertiary but also as primary and secondary treatment systems (for organics and nutrients removal) due to low energy, operational and maintenance costs and good treatment efficiency [101-103]. Although studies in recent years on the elimination of EPs (especially pharmaceuticals and personal care products) in constructed wetlands have been intensified, the vast majority are developed on a small scale (laboratory, pilot), and little information is available on the exploitation of constructed wetlands on a large scale $[103,104]$. Table 6 presents some results regarding the treatment efficiencies of wastewater containing different EPs in various $\mathrm{CW}$ configurations.

Table 6. Efficiency of EPs removal in constructed wetlands (CWs).

\begin{tabular}{|c|c|c|c|c|}
\hline Emerging Pollutant & $\begin{array}{l}\text { Constructed } \\
\text { Wetlands }\end{array}$ & $\begin{array}{c}\text { Removal } \\
\text { Efficiency (\%) }\end{array}$ & $\begin{array}{c}\text { Operating } \\
\text { Scale * }\end{array}$ & References \\
\hline \multirow{8}{*}{ Ibuprofen } & HSSF-CW & 74-99 & & [103] \\
\hline & SF-CW & $45-95$ & & [105] \\
\hline & FW-SW & $\begin{array}{l}\text { 27-74 (winter) } \\
\text { 6-96 (summer) }\end{array}$ & & {$[106,107]$} \\
\hline & SSF-CW & 71 & & [108] \\
\hline & VSSF-CW & $55-99$ & & [103] \\
\hline & SF-CW & $95-96$ & Full scale & [109] \\
\hline & SSF-CW & $71-79.7$ & & [110] \\
\hline & SF-CW & $50-100$ & & [101] \\
\hline \multirow{4}{*}{ Ketoprofen } & FW-SSF & $47-81$ & & [105] \\
\hline & FW-SF & 11-50 (winter) & & {$[106,107]$} \\
\hline & SF-CW & 47-91 & & [103] \\
\hline & HSSF-CW & $10-90$ & & [103] \\
\hline \multirow{8}{*}{ Naproxen } & FW-SSF & $58-81$ & & [105] \\
\hline & FW-SF & $\begin{array}{l}\text { 27-66 (winter) } \\
27-83 \text { (summer) }\end{array}$ & & {$[106,107]$} \\
\hline & SF-CW & $75-76$ & & [103] \\
\hline & HSSF-CW & $76-97$ & & [103] \\
\hline & VSSF-CW & $69-96$ & & [103] \\
\hline & SSF-CW & 85 & & [108] \\
\hline & SF-CW & $52-92$ & & [101] \\
\hline & SF-CW & $82.8-91.3$ & & [110] \\
\hline
\end{tabular}


Table 6. Cont.

\begin{tabular}{|c|c|c|c|c|}
\hline Emerging Pollutant & $\begin{array}{l}\text { Constructed } \\
\text { Wetlands }\end{array}$ & $\begin{array}{c}\text { Removal } \\
\text { Efficiency (\%) }\end{array}$ & $\begin{array}{c}\text { Operating } \\
\text { Scale * }\end{array}$ & References \\
\hline \multirow{4}{*}{ Carbamazepine } & FW-SSF & $35-71$ & & [105] \\
\hline & SSF-CW & 16 & & [108] \\
\hline & SF-CW & $32-37$ & & [111] \\
\hline & SSF-CW & $26.7-28.4$ & & [110] \\
\hline \multirow{3}{*}{ Galaxolide } & FW-SSF & $67-82$ & & [105] \\
\hline & SF-CW & $88-90$ & & [111] \\
\hline & SF-CW & 87 & & [112] \\
\hline \multirow{6}{*}{ Diclofenac } & FW-SF & $\begin{array}{c}\text { 17-26 (winter) } \\
36-52 \text { (summer) }\end{array}$ & Full scale & {$[106,107]$} \\
\hline & SF-CW & $20-50$ & & [103] \\
\hline & HSSF-CW & $24-93$ & & [103] \\
\hline & VSSF-CW & $53-73$ & & [103] \\
\hline & SF-CW & $73-96$ & & [111] \\
\hline & SF-CW & 85 & & [109] \\
\hline \multirow{2}{*}{ Tramadol } & SF-CW & $12-26$ & & [113] \\
\hline & HSSF-CW & $54-85$ & & [103] \\
\hline \multirow{3}{*}{ Paracetamol } & HSSF-CW & 95-100 & & [103] \\
\hline & HSSF-CWs & $>90$ & & [114] \\
\hline & hybrid-CWs & $>95-99$ & & [101] \\
\hline Acetaminophen & HSSF-CWs & $>90$ & & [114] \\
\hline Oxybenzone & HSSF-CWs & $>97$ & & [115] \\
\hline \multirow{3}{*}{ Atenolol } & HSSF-CWs & $58-99$ & & [103] \\
\hline & SF-CWs & $27-53$ & & [113] \\
\hline & HSSF-CWs & 48 & & [48] \\
\hline \multirow{3}{*}{ Metoprolol } & HSSF-CWs & $60-93$ & & [103] \\
\hline & SF-CWs & $3-30$ & & [113] \\
\hline & HSSF-CWs & 11 & & [48] \\
\hline \multirow{2}{*}{ Furosemide } & HSSF-CWs & $80-96$ & & [103] \\
\hline & HSSF-CWs & $35-71$ & & {$[48,115]$} \\
\hline \multirow[b]{2}{*}{ Triclosan } & HSSF-CWs & $62-91$ & & [103] \\
\hline & $\begin{array}{c}\text { Reclamation } \\
\text { pond-wetland }\end{array}$ & $74-93$ & Full scale & [116] \\
\hline \multirow{3}{*}{ ChlorpyrifosMecoprop } & SSF-CWs & $>96$ & & [117] \\
\hline & SF-CWs & 79-91 & & [111] \\
\hline & SSF-CWs & 22 & & [108] \\
\hline
\end{tabular}

* only full scale is mentioned (where available), the rest of results are from laboratory and pilot scales SF-CW: surface-flow constructed wetland; FW-SSF: free water subsurface flow; FW-SF: free water surface flow; HSSF-CW: horizontal subsurface flow constructed wetland; VSSF-CW: vertical subsurface flow constructed wetland.

A number of factors can affect the efficiency of removing EPs in constructed wetland, some of them are described below:

- CWs configuration: different operating modes (subsurface, surface, vertical or horizontal flows) are generated in CWs and are important for the elimination of EPs from 
wastewater through highly oxygen-dependent processes [104]. In this context, the planted vegetation (emerged or submerged and fixed or free-floating) demonstrated significant role in EPs removal; however, the role of plants at microcosm scale, in treating effluents containing emerging pollutants in the constructed wetland system is still a topic of debate $[108,118]$.

- Season of the year: efficiencies during summer operation were generally found higher than those resulted during winter, following higher biodegradation kinetics, plant biomass, variations in influent concentration $[106,119]$. However, a few studies show that the elimination of some personal care products (PCPs) in CWs is not affected by temperature [108]. Therefore, the mechanism by which the season influences the elimination of some EPs and the extent to which this influence occurs requires additional and rigorous studies, especially on the processes that can eliminate EPs, either degradative (biodegradation) or non-degradative (adsorption, absorption by plants).

- $\quad$ Parameters of the influent to be treated: the results obtained by various researchers [102,103] show that CWs can achieve good elimination efficiencies for Biological Oxygen Demand $\left(\mathrm{BOD}_{5}\right)(81.5-95.6 \%)$, Chemical Oxygen Demand (COD) (57.2-84.0\%) and Total Suspended Solids (TSS) (81.7-96.4\%), while the removal of ammonia (17.4-67.0\%) and Total Phosphorous (TP) (5.3-84.1\%) was variable and much lower. However, these results depend on the type, configuration and scale of CWs operation. A rigorous analysis of literature data on the influence of water composition on treatment efficiency can reveal that there is a large dispersion of results, which requires integrated studies and extensive collaborations among research groups, based on robust experimental programs so as to diminish the contradictions between the results.

- Oxygen availability: experimental studies conducted in different cases have established a positive correlation between the concentration of dissolved oxygen in the CWs wastewater influent and the elimination efficiency of emerging pollutant [108].

\subsubsection{Removal of EPs by Membrane Biological Reactors}

The removal of pollutants from wastewater using biological membrane reactor systems (MBR) is considered an efficient one, e.g., by about $15-42 \%$ when compared to the activated sludge system. MBR cannot completely remove EPs alone, so that it is combined usually with ozonation, activated carbon, photodegradation, etc., for polishing the removal [120]. MBR integrates biological and physical processes: the activated sludge treatment and membrane filtration, which can assure good removal efficiencies. Biodegradation, photodegradation, volatilization, sludge absorption of pollutants can occur at long retention times that also allow the elimination of nitrogen and the growth of nitrifying bacteria, which can improve the performance of the process [121,122]. An important advantage is that MBR can operate at relatively low costs, while membrane fouling is a disadvantage [122].

Anaerobic membrane bioreactors (AmMBR) are new and innovative technologies for the treatment of influents with fluctuating pollutant concentrations [123]. AmMBR is based on the anaerobic digestion technology, being characterized by stability and microbial abundance, with good toxic resistance, which ensures a high efficiency of EPs biodegradation. AmMBR can also generate biogas (as renewable bioresource) in significantly larger quantities than the conventional anaerobic biodegradation system, so that it is increasingly used to remove EPs from liquid effluents $[97,103]$. While in the conventional anaerobic process the efficiency of biogas generation is dependent on methanogenic bacteria, solids retention time (SRT) and hydraulic retention time (HRT) [124], in AnMBR, there is a high and stabilized cell concentration built on reasonably high hydraulic load and adequate mixing as a result of totally decoupling HRT from SRT, since membranes hinder biomass being washed out $[125,126]$.

As in the conventional MBR, the membrane fouling in AnMBR is a disadvantage, since it reduces the flow through the membrane and, therefore, makes it necessary to 
ensure larger membrane areas per reactor volume, with increased capital costs, which limits AnMBE application on a larger scale [97,127].

There is a combination of factors that control the membrane fouling, such as $[125,126,128]$ :

- Bioreactor operating conditions (organic loading rate, influent water quality and variability, sludge retention time, hydraulic loading rate, $\mathrm{pH}$, temperature, toxicity of EPs);

- Membrane properties (surface morphology and chemistry, pore size and porosity);

- Hydrodynamic conditions: cross flow velocity, shear stress, gas sparging flow rate and bubbles properties, backwashing potential)

- $\quad$ Process performance (membrane flux, pressure drop, effluent quality, economic aspects);

- Biological properties (biomass concentration, distribution of solid particles, presence of polysaccharides, colloidal particles and soluble microbial products)

- Chemical system characteristics (presence of cations and anions)

The performance of AnMBR can become flexible by selecting the adequate configuration of membrane module as follows (Figure 8) [97,129-133]:

- Side stream:

- The crossflow filtration involves a tangential flow rate, which stimulates the membrane fouling and large energy consumption;

- Easy removal and cleaning of membrane.

- Submerged:

- Can treat high strength industrial wastewater (pharmaceutical and textile wastewaters) [134];

- Membrane fouling can occur being quite difficult to clean.

- External submerged:

- The membrane module is submerged in an external compartment;

- Shear force of water flow is intense, which reduces membrane fouling.

- Anaerobic dynamic membrane bioreactor:

- Low membrane module cost, easy control of membrane fouling;

- Low energy consumption, sludge and biogas production.

- Anaerobic electrochemical membrane bioreactor:

- A microbial electrolysis cell (MEC) combined with membrane filtration;

- Electrically conductive, porous, nickel-based hollow-fiber membranes (NiHFMs).

- Anaerobic osmotic membrane bioreactor:

- A forward osmosis (FO) membrane;

- Salt accumulation and membrane fouling can diminish permeate flux.

A wide variety of EPs can be removed in the AnMBR system, but with various efficiencies, which depend on a number of factors, including the composition of the influent, pollutant, HRT, etc., as is shortly presented in Table 7. 
(a)

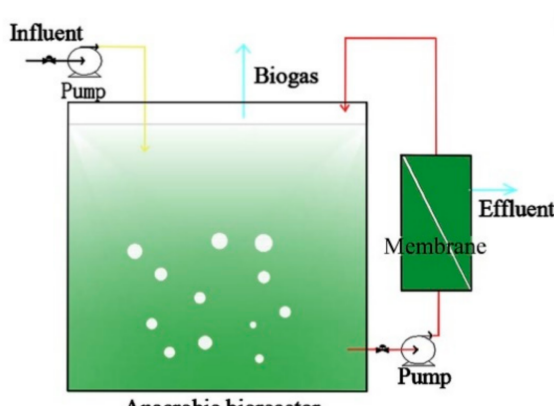

(c)

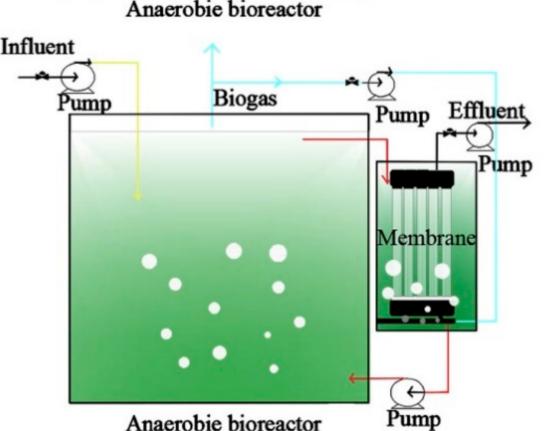

(b)

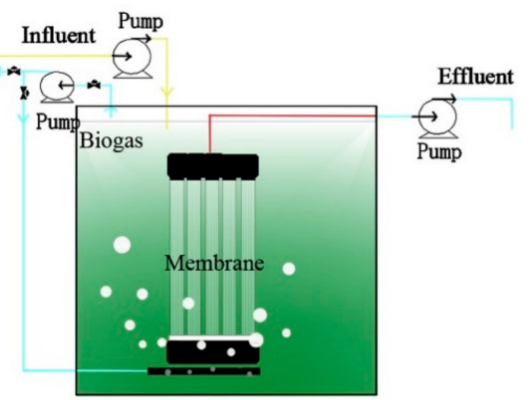

(d)

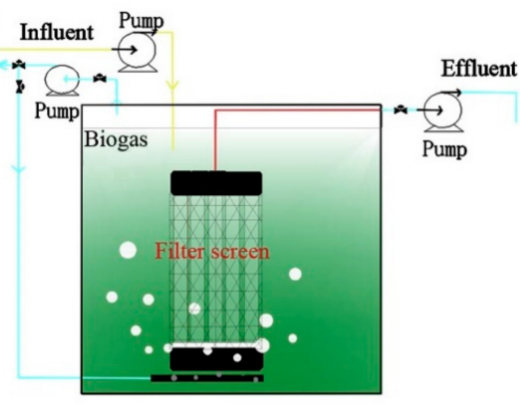

Figure 8. Conventional anaerobic membrane bioreactor (AnMBR) types. Side stream AnMBR (a), submerged AnMBR (b) and external submerged AnMBR (c). Novel AnMBR configurations: anaerobic dynamic membrane bioreactor (d). (Reproduced from [97] with Elsevier permission, license 4963301077334, 6 December 2020).

Table 7. Efficiency of EPs removal in AnMBR system.

\begin{tabular}{ccc}
\hline Emerging Pollutant & Removal Efficiency (\%) & References \\
\hline Bisphenol A & 31.5 & {$[134]$} \\
Androsterone & 98 & {$[134]$} \\
Linuron & 88.1 & {$[135]$} \\
Diazinnon & 80 & {$[136]$} \\
Triclosan & 90.2 & {$[134]$} \\
Ceftriaxone & 47.7 & {$[137]$} \\
Ampicillin & 34.6 & {$[137]$} \\
Amoxicillin & 73.2 & {$[137]$} \\
\hline
\end{tabular}

\subsubsection{Removal of EPs by Biosorption}

Adsorption is the one most applicable and hopeful methods for removing organic and inorganic micropollutants from liquid effluents. The adsorption is a surface process, in which the pollutant and the adsorbent interact through physical and chemical forces. To achieve high adsorption efficiencies, the process is optimized based on experiments that provide information on the influence of factors such as pollutant concentration, adsorbent dose, nature of adsorbent and pollutant, $\mathrm{pH}$, contact time, temperature, presence of other pollutants. Additionally considered are the equilibrium conditions described by adsorption isotherms, which can be represented by models such as Langmuir, Freundlich, Tempkin, Henderson, Halsey, Smith, Elovich, liquid film diffusion, intra-particle diffusion and Lagergren. Adsorption kinetics play an important role in the design of adsorption systems, using kinetic parameters, free energy, enthalpy, entropy and activation energy.

There are frequent studies in literature that discuss the application of various materials as adsorbents for the removal of EPs from polluted liquid streams (Figure 9). New adsorbents were found and studied in the last years together with existing adsorbents, in terms of their capability to immobilize different EPs from aqueous solutions (sorption efficiency, mechanism of interactions involved and the best fit model) $[29,92,138]$ (Figure 10). 


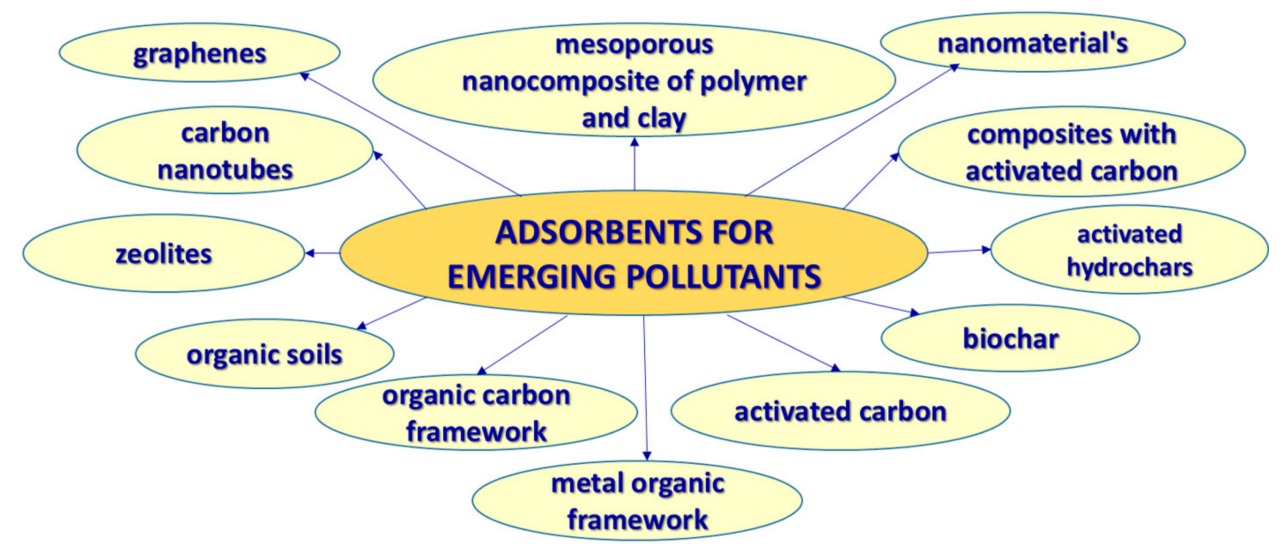

Figure 9. Various categories of adsorbents used in the elimination of emerging pollutants.

A distinctive adsorption process is biosorption-a biological treatment technology that arouses a growing interest nowadays, since a wide range of materials from biomass can play the role of adsorbent. Biosorption can be considered, in general, an effective alternative for the elimination of broad categories of persistent pollutants (inorganic and organic) in the treatment of secondary or tertiary effluents [29]. Biosorption offers some advantages such as low costs due to the abundance of biomass, the possibility of regeneration and recovery of exhausted sorbents and relatively high selectivity compared to conventional techniques (ion exchange, membrane separation, coagulation, etc.) [100,139]. Some advantages of biosorption are shown in Figure 11.

From an economic perspective, biosorption feasibility is dependent on the nature of biomass (vegetable, microbial, algae, etc.), the biosorption capacity of sorbents, the possibilities to modify the sorbent surface to improve the sorption capacity and the chance to regenerate the exhausted biosorbent [140]. Another important aspect, from both economic and ecological points of view is related to the use of biomass waste (from agriculture, food industry, wood industry, etc.) as a source of biosorbents. The removal efficiency of some EPs by biosorption was analyzed by Ahmed et al. [100], as shown in Table 8, for live cultured and harvested white rot fungus (T. versi-colour) in parallel with inactivated biomass by sodium azide, as reported by Nguyen et al. [141]. However, there are a number of unknowns that need to be elucidated regarding the ability and selectivity of the biosorption process to remove EPs from multicomponent mixtures. Additionally, living microbial cells used as biosorbents are difficult to immobilize on a solid support due to their poor mechanical properties [142].

\subsubsection{Hybrid Treatment Schemes}

The efficiency of removing EPs from aqueous media is dependent on the applied removal process and the chemical compound and can show different values, even for the same compound, as can be seen in Table 9. For example, the diclofenac can be removed with an efficiency of $97 \%$ by living microorganisms' uptake (fungi in this case) or of $55 \%$ when treated in horizontal subsurface flow constructed wetland (HSSF-CW). Carbamazepine is removed with low efficiency by biological processes, not exceeding $22 \%$ when treated with HSSF-CW (Table 9). 


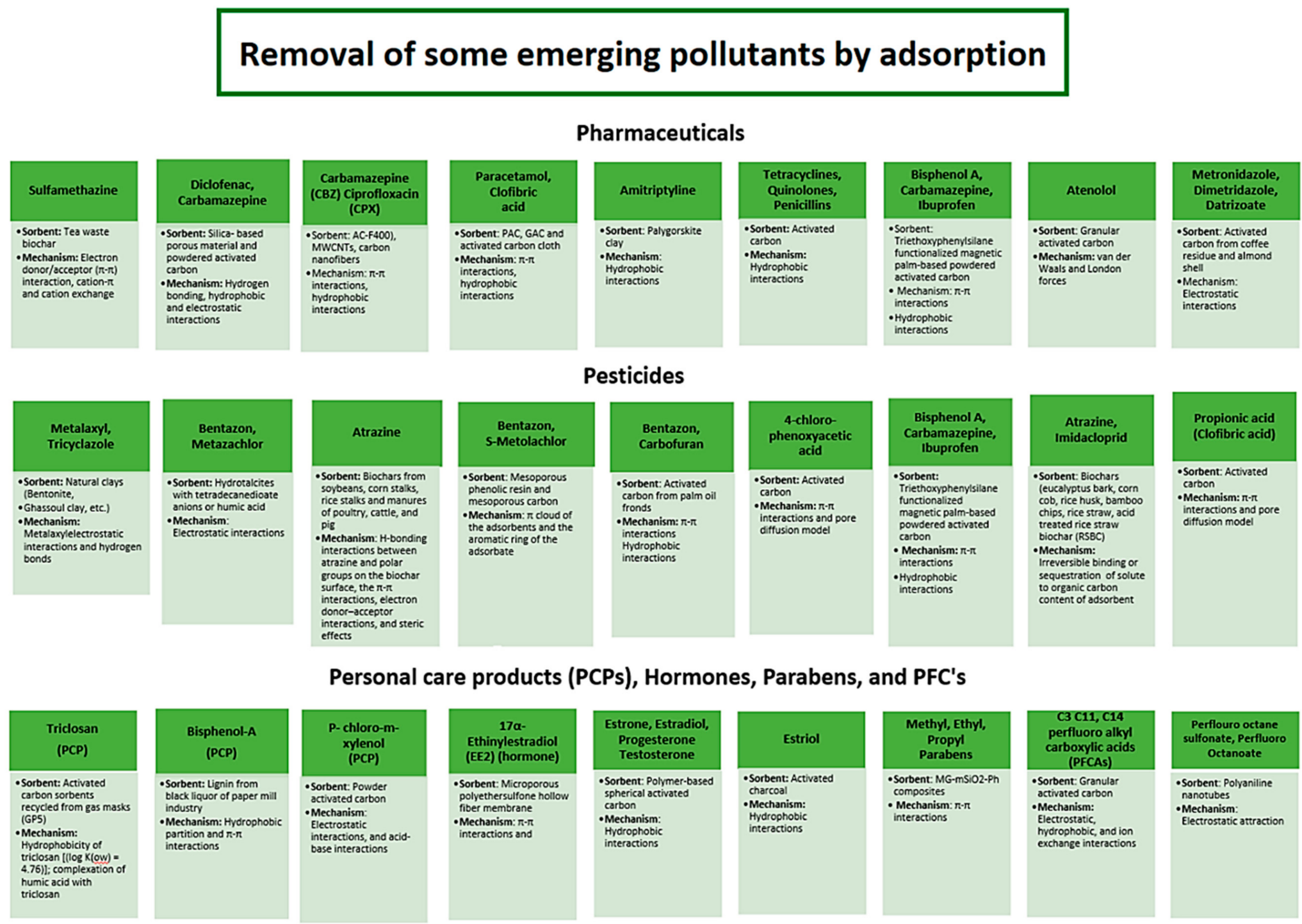

Figure 10. Sorbents and mechanisms for the removal of some emerging pollutants from the environment (adapted upon [29,92]). 


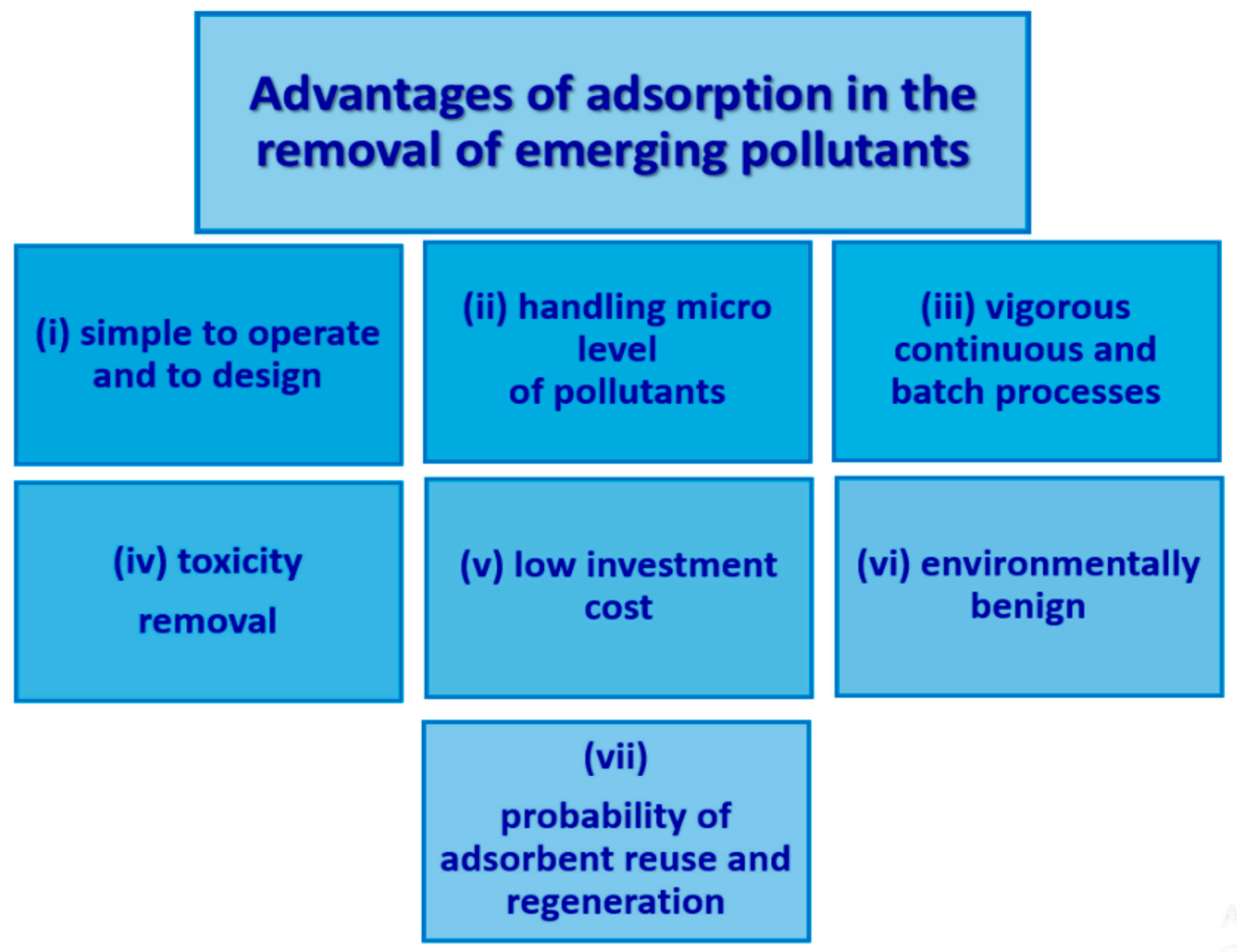

Figure 11. Some advantages of applying biosorption for the removal of emerging pollutants from liquid effluents.

Table 8. EPs removal efficiency by biosorption-based systems [100] *.

\begin{tabular}{|c|c|c|c|c|c|}
\hline \multirow{3}{*}{ Category } & \multirow{3}{*}{ EPs } & \multicolumn{4}{|c|}{ Biosorption } \\
\hline & & \multicolumn{2}{|c|}{ Live (Fungus) } & \multicolumn{2}{|c|}{ Inactivated (Fungus) } \\
\hline & & Influent $\left(\mu \mathrm{gL}^{-1}\right)$ & Removal (\%) & Influent $\left(\mu \mathrm{gL}^{-1}\right)$ & Removal (\%) \\
\hline \multirow{15}{*}{ EDCs ** } & Androstenedione & & & & \\
\hline & Androsterone & & & & \\
\hline & E1 & 50 & 72 & 50 & 31.5 \\
\hline & E2 & 50 & 60.5 & 50 & 29.5 \\
\hline & EE2 & 50 & 62 & $1.50 ; 2.10$ & $1.38 ; 2.76$ \\
\hline & E3 & 50 & 4.5 & 50 & 13 \\
\hline & $17 \beta$-Estradiol-17-acetate & 50 & 79 & 50 & 84 \\
\hline & Bisphenol A & 50 & 65 & $1.50 ; 2.10$ & $1.24 ; 2.59$ \\
\hline & 4-tert-butylphenol & 50 & 33 & 50 & 10.5 \\
\hline & nonylphenol & & & & \\
\hline & Octylphenol & & & & \\
\hline & 4-tert-octylphenol & & 90 & & 82.5 \\
\hline & 4-n-nonylphenol & & & & \\
\hline & Testosterone & & & & \\
\hline & Dihydrotesterone & & & & \\
\hline \multirow{6}{*}{ Pesticides } & Atrazine & 50 & 18 & 50 & 9 \\
\hline & Dicamba & & & & \\
\hline & Fenoprop & 50 & 01 & 50 & 0 \\
\hline & $2,4-\mathrm{D}$ & & & & \\
\hline & Mecoprop & & & & \\
\hline & Pentachlorophenol & 50 & 63 & 50 & 96 \\
\hline
\end{tabular}


Table 8. Cont.

\begin{tabular}{|c|c|c|c|c|c|}
\hline \multirow{3}{*}{ Category } & \multirow{3}{*}{ EPs } & \multicolumn{4}{|c|}{ Biosorption } \\
\hline & & \multicolumn{2}{|c|}{ Live (Fungus) } & \multicolumn{2}{|c|}{ Inactivated (Fungus) } \\
\hline & & Influent $\left(\mu \mathrm{gL}^{-1}\right)$ & Removal (\%) & Influent $\left(\mu g^{-1}\right)$ & Removal (\%) \\
\hline Beta-blockers & $\begin{array}{c}\text { Triclosan } \\
\text { Atendol } \\
\text { Metoprolol } \\
\text { Nadolol } \\
\text { Propranolol } \\
\text { Sotalol } \\
\text { Salbutamol }\end{array}$ & 50 & 78.5 & 50 & 97 \\
\hline PCPs ** & $\begin{array}{l}\text { Benzophenone } \\
\text { Oxybenzene } \\
\text { Propyl parabene } \\
\text { Salicylic acid }\end{array}$ & $\begin{array}{l}50 \\
50 \\
50\end{array}$ & $\begin{array}{c}40 \\
54.5 \\
68\end{array}$ & $\begin{array}{c}1.50 ; 2.10 \\
50\end{array}$ & $\begin{array}{c}1.11 .5 ; 2.83 \\
59.5 \\
0\end{array}$ \\
\hline Antiplatelet agents & $\begin{array}{c}\text { Codeine } \\
\text { Paracetamol }\end{array}$ & & & & \\
\hline Anxiety relievers & $\begin{array}{l}\text { Clopidogrel } \\
\text { Hydrocodone }\end{array}$ & & & & \\
\hline Antagonists & Diazepam & & & & \\
\hline Pain-relievers & Famotidine & & & & \\
\hline Gastroesophageal & $\begin{array}{c}\text { Lorazepam } \\
\text { Ranitidine }\end{array}$ & & & & \\
\hline Analgesics & $\begin{array}{c}\text { Carbamazepine } \\
\text { Citalopram } \\
\text { Diclofenac } \\
\text { Ibuprofen } \\
\text { Lorazepan } \\
\text { Metronidazole } \\
\text { Naprox } \\
\text { Primidone } \\
\text { Trazodone }\end{array}$ & $\begin{array}{l}50 \\
50 \\
50\end{array}$ & $\begin{array}{c}01 \\
97 \\
100\end{array}$ & $\begin{array}{l}50 \\
50 \\
50\end{array}$ & $\begin{array}{l}07 \\
43 \\
27\end{array}$ \\
\hline Anti-depressants & Amitriptyline & 50 & 05 & 50 & 09 \\
\hline Anticonvulsants & Ketoprofen & 50 & 22 & 50 & 11 \\
\hline Lipid regulators & $\begin{array}{l}\text { Clofibric acid } \\
\text { Gemifibrozil }\end{array}$ & $\begin{array}{l}50 \\
50\end{array}$ & $\begin{array}{c}06 \\
100\end{array}$ & $\begin{array}{l}50 \\
50\end{array}$ & $\begin{array}{c}18 \\
57.5\end{array}$ \\
\hline Diuretics & $\begin{array}{l}\text { Hydrochlorothiazide } \\
\text { Furosemide }\end{array}$ & & & & \\
\hline Antibiotics & $\begin{array}{l}\text { Azithromycin } \\
\text { Clarithromycin } \\
\text { Erythromycin } \\
\text { Ofloxacin } \\
\text { Sulfamethaxazole } \\
\text { Trimethoprim }\end{array}$ & & & & \\
\hline Anti-inflammatory & Acetaminophen & & & & \\
\hline Stimulant & Caffeine & & & & \\
\hline
\end{tabular}

* reproduced from [100] with Elsevier permission, License 4912441171076 of 19 September 2020. ${ }^{* *}$ EDCs—endocrine disrupting chemicals, PCPs-personal care products. 
Table 9. Comparison of removal efficiency of some processes involving biological technologies for the removal of several emerging pollutants.

\begin{tabular}{cccccc}
\hline & \multicolumn{3}{c}{ Removal Efficiency, \% } \\
\cline { 2 - 6 } Emerging Pollutant & & & & \multicolumn{2}{c}{ Biosorption [144] } \\
\cline { 3 - 7 } & HSSF-CW [120] & Lab-Scale MBR [143] & Biological Filtration [111] & $\begin{array}{c}\text { Live } \\
\text { Fungus }\end{array}$ & $\begin{array}{c}\text { Inactivated } \\
\text { Fungus }\end{array}$ \\
\hline Diclofenac & 55 & 58 & 93 & 97 & 43 \\
Carbamazepine & 26 & 13 & 5 & 1 & 7 \\
Naproxen & 91 & - & - & 100 & 9 \\
Atrazine & - & 9 & -18 & 9 \\
\hline
\end{tabular}

To streamline the elimination of a greater diversity of EPs, some hybrid treatment schemes have recently been applied, and significant improvements were noticed in the treatment efficiency [100].

Hybrid systems are able to ensure maximum removal efficiency of EPs, achieved in a first step by biological processes, followed by physico-chemical processes, which complete the treatment (Table 10). Such hybrid processes may be, for example $[100,101]$ :

- Activated sludge process + membrane separation/filtration systems (reverse osmosis, ultrafiltration) + gamma radiations;

- Constructed wetlands coupled with waste stabilization ponds (removal of pharmaceuticals, beta-blockers), or biodegradation, or/and sorption, or/and volatilization, or/and hydrolysis, or/and photodegradation;

- Membrane bioreactor (MBR) + membrane separation/filtration systems (reverse osmosis, nanofiltration) (removal of pesticides, pharmaceuticals, beta-blocking drugs);

- Membrane bioreactor (MBR) + UV oxidation, or adsorption on activated carbon, or ozonation followed by ultrasounds;

- Ozonation + biological activated carbon (drugs: antibiotics, antidepressants, beta blockers, endocrine disrupting chemicals, pesticides);

- Flocculants + activated sludge + ultrafiltration (endocrine disrupting chemicals, pesticides, beta blockers);

- Ultrafiltration + activated carbon + ultrasounds (antibiotics);

- Surface flow constructed wetland (SFCW) + horizontal flow constructed wetland (HFCW) (drugs: beta blockers, stimulants).

Overall, the hybrid systems show attractive potential for the EPs removal, but complete removal was not always observed. Therefore, it is necessary to extend research and experiments, up to large scale, to explore hybrid treatment technologies that also integrate photochemical, electrochemical and other treatments with biological ones. 
Table 10. Efficiency of EP removal achieved by hybrid systems.

\begin{tabular}{|c|c|c|c|c|}
\hline Emerging Pollutant & First Step & Second Step & Removal Efficiency, \% & Reference \\
\hline Propanolol & Membrane Biological Reactor & Reverse Osmosis & 99.5 & {$[145,146]$} \\
\hline \multirow{3}{*}{ Diclofenac } & Membrane Biological Reactor & Reverse Osmosis & 95 & [146] \\
\hline & Activated sludge + Ultrafiltration & Ultrasounds & 99.7 & [146] \\
\hline & Membrane Biological Reactor & Electrochemical Process & 75 & [147] \\
\hline Ibuprofen & Biological Activated Carbon & Ultrafiltration & 45 & [148] \\
\hline Bisphenol A & Flocculants + Activated Sludge & Ultrafiltration & 95 & [149] \\
\hline Sulfonamides & Membrane Biological Reactor & Reverse Osmosis & $>93$ & [146] \\
\hline \multirow{4}{*}{ Salicylic acid } & Membrane Biological Reactor & Ultrafiltration & 92.6 & [144] \\
\hline & Membrane Biological Reactor & Nanofiltration & 97.3 & [144] \\
\hline & Membrane Biological Reactor & Reverse Osmosis & 95.4 & {$[144]$} \\
\hline & Activated sludge & $\begin{array}{l}\text { Ultrafiltration }+ \text { Reverse } \\
\text { Osmosis }\end{array}$ & 99.9 & [144] \\
\hline \multirow{4}{*}{ Clarithromycin } & Membrane Biological Reactor & Reverse Osmosis & 99.5 & [145] \\
\hline & Ozonation & Ultrasound & 94.3 & [150] \\
\hline & Ozonation & Ultrasound & 100 & [150] \\
\hline & Activated sludge & $\begin{array}{l}\text { Ultrafiltration }+ \text { Reverse } \\
\text { Osmosis }\end{array}$ & 95.9 & [146] \\
\hline Atrazine & Biological Activated Carbon & Ozonation & 70 & [151] \\
\hline \multirow{2}{*}{ Pentachlorophenol } & Membrane Biological Reactor & Reverse Osmosis & 99 & [144] \\
\hline & Membrane Biological Reactor & UV Oxidation & 99 & [144] \\
\hline $2,4-\mathrm{D}$ & Biological Activated Carbon & Ozonation & 92.9 & [151] \\
\hline
\end{tabular}

\section{Conclusions}

The occurrence of emerging pollutants in the environment continue to generate increasingly stringent problems. Thanks to the increase in water monitoring and development of new analytical techniques mixtures of emerging chemicals are detected in aquatic environments. Even if they can be present at very low concentrations (ng/L), their impact on environmental and human health may be significant.

Source reduction and substitution of emerging pollutants with products having lower toxicity and easier to remove from water can play an important role in reducing the impact of EPs on the environment and human health but are not feasible in all cases. Studies on the elimination of emerging pollutants need to be focused on robust remediation processes developed on sustainable bases, designed to ensure consistency between pollutants characteristics and the possibility of integrating several removal processes to ensure compliance with regulations. Future technologies need to be both effective and environmentally friendly treatments, capable of removing the widest possible spectrum of emerging pollutants, with low energy consumption and capital expenditures. Moreover, the efficiency of the treatment has to be adjustable to emerging pollutants concentrations in the aquatic environment and to make it possible to recover the treated water.

Author Contributions: Conceptualization, I.C.V., M.G.; writing—original draft preparation, I.C.V., D.M.A., D.I.F.; writing — review and editing, M.G.; funding acquisition, M.G. All authors have read and agreed to the published version of the manuscript.

Funding: This work was supported by a grant of the Romanian National Authority for Scientific Research, CNCS-UEFISCDI, project number PN-III-P4- ID-PCE-2016-0683, Contract no. 65/2017, and a grant of the Romanian Ministry of Education and Research, CCCDI-UEFISCDI, project number PN-III-P2-2.1-PED-2019-5239, Contract no. 269PED/2020, within PNCDI III. 
Institutional Review Board Statement: Not applicable.

Informed Consent Statement: Not applicable.

Data Availability Statement: Data is contained within the article.

Conflicts of Interest: The authors declare no conflict of interest. The funders had no role in the design of the study; in the collection, analyses, or interpretation of data; in the writing of the manuscript, or in the decision to publish the results.

\section{References}

1. Bunke, D.; Moritz, S.; Brack, W.; Herráez, D.L.; Posthuma, L.; Nuss, M. Developments in society and implications for emerging pollutants in the aquatic environment. Environ. Sci. Eur. 2019, 31, 32. [CrossRef]

2. Caliman, F.A.; Gavrilescu, M. Pharmaceuticals, personal care products and endocrine disrupting agents in the environment-A review. Clean (Weinh) 2009, 37, 277-303. [CrossRef]

3. Gavrilescu, M.; Demnerová, K.; Aamand, J.; Agathos, S.; Fava, F. Emerging pollutants in the environment: Present and future challenges in biomonitoring, ecological risks and bioremediation. $N$ Biotechnol. 2015, 32, 147-156. [CrossRef]

4. Geissen, V.; Mol, H.; Klumpp, E.; Umlauf, G.; Nadal, M.; van der Ploeg, M.; van de Zee, S.E.A.T.M.; Ritsema, C.J. Emerging pollutants in the environment: A challenge for water resource management. Int. Soil Water Conserv. Res. 2015, 3, 57-65. [CrossRef]

5. Water for People, Water for Life (2003): 3rd World Water Forum in Kyoto, Japan. www.Norman-Network.net.USEPA. 2011. Exposure Factors Handbook 2011 Edition (Final). EPA/600/R-09/052F. USEPA: Washington, DC, USA. Available online: http:/ / www.epa.gov/ncea/efh (accessed on 16 August 2020).

6. Stefanakis, A.; Becker, J.A. A review of emerging contaminants in water: Classification, sources, and potential risks in: Impact of water pollution on human health and environmental sustainability. IGI Glob. 2016. [CrossRef]

7. Zwiener, C.; Frimmel, F.H. ILC-MS analysis in the aquatic environment and in water treatmen-a critical review. Part II. Applications for emerging contaminants and related pollutants, microorganisms and human-acids. Anal. Bioanal. Chem. 2004, 378, 862-874. [CrossRef]

8. Directive 2000/60/EC of the European Parliament and of the Council of 23 October 2000 Establishing a Framework for Community Action in the Field of Water Policy. Off. J. Eur. Union 2000, 1-73. Available online: https:/ / eur-lex.europa.eu/resource.html?uri= cellar:5c835afb-2ec6-4577-bdf8-756d3d694eeb.0004.02/DOC_1\&format=PDF (accessed on 16 August 2020).

9. Ferreiro, V.; Gómez-Motos, I.; Lombrana, J.I.; de Luis, A.; Villota, N.; Ros, O.; Etxebarria, N. Contaminants of emerging concern removal in an effluent of wastewater treatment plant under biological and continuous mode ultrafiltration treatment. Water 2020, 12, 725. [CrossRef]

10. Du, B.; Haddad, S.P.; Scott, W.C.; Chambliss, C.K.; Brooks, B.W. Pharmaceutical bioaccumulation by periphyton and snails in an effluent-dependent stream during an extreme drought. Chemosphere 2015, 119, 927-934. [CrossRef]

11. Petrie, B.; Barden, R.; Kasprzyk-Hordern, B. A review on emerging contaminants in wastewaters and the environment: Current knowledge, understudied areas and recommendations for future monitoring. Water Res. 2015, 72, 3-27. [CrossRef]

12. Snow, D.D.; Cassada, D.A.; Larsen, M.L.; Mware, N.A.; Li, X.; D’Alessio, M.; Zhang, Y.; Sallach, J.B. Detection, occurrence and fate of emerging contaminants in agricultural environments. Water Environ. Res. 2017, 89, 897-920. [CrossRef] [PubMed]

13. Lei, M.; Zhang, L.; Lei, J.; Zong, L.; Li, J.; Wu, Z.; Wang, Z. Overview of emerging contaminants and associated human health effects. BioMed Res. Int. 2015, 404796. [CrossRef]

14. Gogoi, A.; Mazumder, P.; Tyagi, V.K.; Chaminda, T.G.G.; Kyoungjin An, A.; Kumar, M. Occurrence and fate of emerging contaminants in water environment: A review. Groundw. Sustain. Dev. 2018, 6, 169-180. [CrossRef]

15. Tang, T. Emerging indoor pollutants. Int. J. Hyg. Environ. Health 2020, 224. [CrossRef]

16. Tang, Y.; Yin, M.; Yang, W.; Li, H.; Zhong, Y.; Mo, L.; Liang, Y.; Ma, X.; Sun, X. Emerging pollutants in water environment: Occurrence, monitoring, fate, and risk assessment. Water Environ. Res. 2019, 91, 984-991. [CrossRef] [PubMed]

17. Gomes, A.R.; Justino, C.; Rocha-Santos, T.; Freitasd, A.C.; Duarte, A.C.; Pereira, R. Review of the ecotoxicological effects of emerging contaminants on soil biota. J. Environ. Sci. Health A 2017. [CrossRef]

18. Hlavinek, P.; Zizlavska, A. Occurrence and Removal of Emerging Micropollutants from Urban Wastewater. In Water Management and the Environment: Case Studies; Zelenakova, M., Ed.; Springer International Publishing AG: Cham, Switzerland, 2018; pp. 231254. [CrossRef]

19. Risk Assessment Guidance for Superfund Volume 1. Human Health Evaluation Manual (Part E, Supplemental Guidance for Dermal Risk Assessment), EPA/540/R/99/005 Office of Superfund Remediation and Technology Innovation. U.S. Environmental Protection Agency: Washington, DC, USA. Available online: https:/ /www.epa.gov/sites/production/files/2015-09/documents/ part_e_final_revision_10-03-07.pdf (accessed on 12 October 2020).

20. Contaminants of Emerging Concern including Pharmaceuticals and Personal Care Products. United States Environmental Protection Agency (USEPA): Washington, DC, USA. Available online: https:/ / www.epa.gov/wqc/contaminants-emergingconcern-including-pharmaceuticals-and-personal-care-products (accessed on 12 October 2020).

21. Rivera-Utrilla, J.; Sánchez-Polo, M.; Ferro-García, M.Á.; Prados-Joya, G.; Ocampo-Pérez, R. Pharmaceuticals as emerging contaminants and their removal from water. A review. Chemosphere 2013, 93, 1268-1287. [CrossRef] [PubMed] 
22. Hernández, F.; Sancho, J.V.; Ibáñez, M.; Guerrero, C. Antibiotic residue determination in environmental waters by LC-MS. Trends Anal. Chem. 2007, 26, 466-485. [CrossRef]

23. Boyd, G.R.; Reemtsma, H.; Grimm, D.A.; Mitra, S. Pharmaceuticals and personal care products (PPCPs) in surface and treated waters of Louisiana, USA and Ontario, Canada. Sci. Total Environ. 2003, 311, 135-149. [CrossRef]

24. Petrović, M.; Hernando, M.D.; Díaz-Cruz, M.S.; Barceló, D. Liquid chromatography-tandem mass spectrometry for the analysis of pharmaceutical residues in environmental samples: A review. J. Chromatogr. A 2005, 1067, 1-14. [CrossRef] [PubMed]

25. Richardson, S.D. Environmental mass spectrometry: Emerging contaminants and current issues. Anal. Chem. 2006, 78, 4021-4074. [CrossRef] [PubMed]

26. Dargnat, C.; Teil, M.J.; Chevreuil, M.; Blanchard, M. Phthalate removal throughout wastewater treatment plant Case study of Marne aval station (France). Sci. Total Environ. 2009, 407, 1235-1244. [CrossRef] [PubMed]

27. Deblonde, T.; Cossu-Leguille, C.; Hartemann, P. Emerging pollutants in wastewater: A review of the literature. Int. J. Hyg. Environ. Health 2011, 214, 442-448. [CrossRef] [PubMed]

28. Sanchez-Avila, J.; Bonet, J.; Velasco, G.; Lacorte, S. Determination and occurrence of phthalates, alkylphenols, bisphenol A, PBDEs, PCBs and PAHs in an industrial sewage grid discharging to a Municipal Wastewater Treatment Plant. Sci. Total Environ. 2009, 407, 4157-4167. [CrossRef]

29. Basheer, A. New generation nano-adsorbents for the removal of emerging contaminants in water. J. Mol. Liq. 2018, 261, 583-593. [CrossRef]

30. Miège, C.; Choubert, J.-M.; Ribeiro, L.; Eusèbe, M.; Coquery, M. Le devenir des résidus pharmaceutiques dans les stations d'épuration d'eaux usées. Une synthèse de la littérature. Tech. Sci. Méthode 2009, 11, 75-94. [CrossRef]

31. Wiebke, W.; Nodler, K.; Farinelli, A.; Blum, J.; Licha, T. Integrated approach for innovative monitoring strategies of reservoirs and lakes. Environ. Eng. Manag. J. 2018, 17, 2497-2505. [CrossRef]

32. Yehya, T.; Favier, L.; Kadmi, Y.; Audonnet, F.; Fayad, N.; Gavrilescu, M.; Vial, C. Removal of carbamazepine by electrocoagulation: Investigation of some key operational parameters. Environ. Eng. Manag. J. 2015, 14, 639-645. [CrossRef]

33. Dapcevich, M. Antibiotics Found in Global Rivers Exceed 'Safe' Levels, Study Finds. EcoWatch. 2019. Available online: https: / / www.ecowatch.com/antibiotics-global-rivers-2638404371.html (accessed on 10 August 2020).

34. OECD. Pharmaceutical Residues in Freshwater: Hazards and Policy Responses; Organisation for Economic Co-Operation and Development: Paris, France, 2019. [CrossRef]

35. Roston, B.A. Antibiotics Found in Rivers at Up. SlashGear 2019. Available online: https://www.slashgear.com/antibioticsfound-in-rivers-at-up-to-300-times-over-safe-levels-27578126/ (accessed on 15 July 2020).

36. Cycon, M.; Mrozik, A.; Piotrowska-Sege, Z. Antibiotics in the soil environment-Degradation and their impact on microbial activity and diversity. Front. Microbiol. 2019. [CrossRef]

37. Kraemer, S.A.; Ramachandran, A.; Perron, G.G. Antibiotic pollution in the environment: From microbial ecology to public policy. Microorganisms 2019, 7, 180. [CrossRef] [PubMed]

38. Stamm, C.; Rasanen, K.; Burdon, F.J.; Altermatt, F.; Jokela, J.; Joss, A.; Ackermann, M.; Eggen, R.I.L. Unravelling the impacts of micropollutants in aquatic ecosystems: Interdisciplinary studies at the interface of large-scale ecology. Adv. Ecol. Res. 2016, 55, 183-222. [CrossRef]

39. Bao, L.-J.; Wei, Y.-L.; Yao, Y.; Ruan, Q.-Q.; Zeng, E.Y. Global trends of research on emerging contaminants in the environment and humans: A literature assimilation. Environ. Sci. Pollut. Res. 2015, 22, 1635-1643. [CrossRef] [PubMed]

40. Manickum, T.; John, W. Occurrence, fate and environmental risk assessment of endocrine disrupting compounds at the wastewater treatment works in Pietermaritzburg (South Africa). Sci. Total Environ. 2014, 468-469, 584-597. [CrossRef] [PubMed]

41. Ternes, T.A. Emerging Substances in Water. A New Challenge for Water Management. 2006. Available online: https://www. norman-network.net/sites / default/ files / files /Events / 2006-2008/2006Jun19-20-Stresa-EmEnvPollutants-KeyIssuesChallenges / 03-sess1_ternes.pdf (accessed on 10 July 2020).

42. Richardson, S.D.; Ternes, T.A. Water analysis: Emerging contaminants and current issues. Anal. Chem. 2005, 77, 3807-3838. [CrossRef] [PubMed]

43. Giokas, D.L.; Sakkas, V.A.; Albanis, T.A.; Lampropoulou, D.A. Determination of UV-filter residues in bathing waters by liquid chromatography UV-diode array and gas chromatography-mass spectrometry after micelle mediated extraction-solvent back extraction. J. Chromatogr. A 2005, 1077, 19-27. [CrossRef] [PubMed]

44. Hiller, J.; Klotz, K.; Meyer, S.; Uter, W.; Hofa, K.; Greinera, A.; Goen, T.; Drexler, H. Systemic availability of lipophilic organic UV filters through dermal sunscreen exposure. Environ. Int. 2019, 132, 105068. [CrossRef] [PubMed]

45. Sharifan, H.; Klein, D.; Morse, A.N. UV filters are an environmental threat in the Gulf of Mexico: A case study of Texas coastal zones. Oceanologia 2016, 58, 327-335. [CrossRef]

46. Wang, J.; Pan, L.; Wu, S.; Lu, L.; Xu, Y.; Zhu, Y.; Guo, M.; Zhuang, S. Recent advances on endocrine disrupting effects of UV filters. Int. J. Environ. Res. Public. Health 2016, 13, 782. [CrossRef]

47. Zhou, X.; Peng, F.; Luo, Z.; Li, Y.; Li, H.; Yang, Z. Assessment of water contamination and health risk of endocrine disrupting chemicals in outdoor and indoor swimming pools. Sci. Total Environ. 2020, 704, 135277. [CrossRef] [PubMed]

48. Ramos, S.; Homem, V.; Alves, A.; Santos, L. A review of organic UV-filters in wastewater treatment plants. Environ. Int. 2016, 86, 24-44. [CrossRef] 
49. Magi, E.; Scapolla, C.; Di Carro, M.; Rivaro, P.; Nguyen, K.T.N. Emerging pollutants in aquatic environments: Monitoring of UV filters in urban wastewater treatment plants. Anal. Methods 2013, 5, 428. [CrossRef]

50. Regulation (EC) No. 1223/2009 of the European Parliament and of the Council of 30 November 2009 on Cosmetic Products. Brussels. 22 December 2009. Available online: http:/ / eur-lex.europa.eu/LexUriServ /LexUriServ.do?uriDOJ:L:2009:342:0059: 0209:en:PDF (accessed on 25 August 2020).

51. Cadena-Aizaga, M.I.; Montesdeoca-Esponda, S.; Torres-Padrón, M.E.; Sosa-Ferrera, Z.; Santana-Rodríguez, J.J. Organic UV filters in marine environments: An update of analytical methodologies, occurrence and distribution. Trends Environ. Anal. Chem. 2020, 25, e00079. [CrossRef]

52. Regulation (EC) No. 1907/2006 of the European Parliament and of the Council of 18 December 2006 Concerning the Registration, Evaluation, Authorization and Restriction of Chemicals (REACH). Brussels. 29 May 2007. Available online: http://eur-lex. europa.eu/LexUriServ/LexUriServ.do?uriDOJ:L:2007:136:0003:0280:EN:PDF (accessed on 25 August 2020).

53. Regulation No. 726/2004 of the European Parliament and of the Council of 31 March 2004 Laying Down Community Procedures for the Authorization and Supervision of Medicinal Products for Human and Veterinary Use and Establishing a European Medicines Agency. Brussels. 30 April 2004. Available online: http:/ / eur-lex.europa.eu/legal-content/EN/TXT/PDF/ ?uriDCELEX:32004R0726\&fromDEN (accessed on 25 August 2020).

54. Regulation (EC) No. 1107/2009 of the European Parliament and of the Council of 21 October 2009 Concerning the Placing of Plant Protection Products on the Market and Repealing Council Directives 79/117/EEC and 91/414/EEC. Brussels. 24 November 2009. Available online: http:/ / eur-lex.europa.eu/legal-content/EN/TXT/PDF/?uriDCELEX:32009R1107\&fromDEN (accessed on 25 August 2020).

55. Carere, M.; Polesello, S.; Kase, R.; Gawlik, B.M. The Emerging Contaminants in the Context of the EU Water Framework Directive. In Emerging Contaminants in River Ecosystems; Petrovic, M., Sabater, S., Elosegi, A., Barceló, D., Eds.; Springer International Publishing: Cham, Switzerland, 2016; pp. 197-216. [CrossRef]

56. Sorlini, S.; Collivignarelli, M.C.; Miino, M.C. Technologies for the control of emerging contaminants in drinking water treatment plants. Environ. Eng. Manag. J. 2019, 18, 2203-2213. Available online: http://www.eemj.icpm.tuiasi.ro/pdfs/vol18/no10/11_85_ Sorlini_19.pdf (accessed on 16 August 2020).

57. Verlicchi, P.; Al Aukidy, M.; Zambello, E. Occurrence of pharmaceutical compounds in urban wastewater: Removal, mass load and environmental risk after a secondary treatment-a review. Sci. Total Environ. 2013, 429, 123-155. [CrossRef] [PubMed]

58. Bradley, P.M.; Barber, L.B.; Kolpin, D.W.; McMahon, P.B.; Chapelle, F.H. Potential for 4-n-nonylphenol biodegradation in stream sediments. Environ. Toxicol. Chem. 2008, 27, 260-265. [CrossRef]

59. Barra Caracciolo, A.; Grenni, P.; Rauseo, J.; Ademollo, N.; Cardoni, M.; Rolando, L.; Patrolecco, L. Degradation of a fluoroquinolone antibiotic in an urbanized stretch of the River Tiber. Microchem. J. 2018, 136, 43-48. [CrossRef]

60. Miraji, H.; Othman, O.C.; Ngassapa, F.N.; Mureithi, E.W. Research trends in emerging contaminants on the aquatic environments of Tanzania. Scientifica (Cairo) 2016, 3769690. [CrossRef]

61. Mortensen, A.; Granby, K.; Eriksen, F.D.; Cederberg, T.L.; Friis-Wandall, S.; Simonsen, Y.; Broesbøl-Jensen, B.; Bonnichsen, R. Levels and risk assessment of chemical contaminants in byproducts for animal feed in Denmark. J. Environ. Sci. Health B 2014, 49, 797-810. [CrossRef] [PubMed]

62. Naidu, R.; Arias Espana, V.A.; Liu, Y.; Jit, J. Emerging contaminants in the environment: Risk-based analysis for better management. Chemosphere 2016, 154, 350-357. [CrossRef]

63. Wollenberger, L.; Halling-Sørensen, B.; Kusk, K.O. Acute and chronic toxicity of veterinary antibiotics to Daphnia magna. Chemosphere 2000, 40, 723-730. [CrossRef]

64. Tratnyek, P.G.; Weber, E.J.; Schwarzenbach, R.P. Quantitative structure-activity relationships for chemical reductions of organic contaminants. Environ. Toxicol. Chem. 2009, 22, 1733-1742. [CrossRef] [PubMed]

65. Lin, X.; Xu, J.; Keller, A.A.; He, L.; Gu, Y.; Zheng, W.; Sun, D.; Lu, Z.; Huang, J.; Huang, X.; et al. Occurrence and risk assessment of emerging contaminants in a water reclamation and ecological reuse project. Sci. Total Environ. 2020, 744, 140977. [CrossRef] [PubMed]

66. Ma, X.Y.; Li, Q.; Wang, X.C.; Wang, Y.; Wang, D.; Ngo, H.H. Micropollutants removal and health risk reduction in a water reclamation and ecological reuse system. Water Res. 2018, 138, 272-281. [CrossRef] [PubMed]

67. Guidelines for Human Exposure Assessment, Risk Assessment Forum. United States Environmental Protection Agency (USEPA): Washington, DC, USA. Available online: https://www.epa.gov/sites/production/files/2020-01/documents/guidelines_for_ human_exposure_assessment_final2019.pdf (accessed on 16 August 2020).

68. Hang, C.; Zhang, B.; Gong, T.; Xian, Q. Occurrence and health risk assessment of halogenated disinfection byproducts in indoor swimming pool water. Sci. Total Environ. 2016, 543, 425-431. [CrossRef] [PubMed]

69. Gavrilescu, M. Fate of pesticides in the environment and its bioremediation. Eng. Life Sci. 2005, 5, 497-526. [CrossRef]

70. Panahandeh, M.; Mansouri, N.; Khorasani, N.; Karbassi, A.R. A study of pollution in sediments from anzali wetland with geo-accumulation index and ecological risk assessment. Environ. Eng. Manag. J. 2018, 17, 2255-2262.

71. Dsikowitzky, L.; Crawford, S.E.; Nordhaus, I.; Lindner, F.; Dwiyitno; Irianto, H.E.; Ariyani, F.; Schwarzbauer, J. Analysis and environmental risk assessment of priority and emerging organic pollutants in sediments from the tropical coastal megacity Jakarta, Indonesia. Reg. Stud. Mar. Sci. 2020, 34, 101021. [CrossRef] 
72. Al Aukidy, M.; Verlicchi, P.; Jelic, A.; Petrovi, M.; Barcelo, D. Monitoring release of pharmaceutical compounds: Occurrence and environmental risk assessment of two WWTP effluents and their receiving bodies in the Po Valley, Italy. Sci. Total Environ. 2012, 438, 15-25. [CrossRef]

73. Stuart, M.; Lapworth, D.; Crane, E.; Hart, A. Review of risk from potential emerging contaminants in UK groundwater. Sci. Total Environ. 2012, 416, 1-21. [CrossRef]

74. Sanchez, W.; Egea, E. Health and environmental risks associated with emerging pollutants and novel green processes. Environ. Sci. Pollut. Res. 2018, 25, 6085-6086. [CrossRef]

75. Riva, F.; Zuccato, E.; Davoli, E.; Fattore, E.; Castiglioni, S. Risk assessment of a mixture of emerging contaminants in surface water in a highly urbanized area in Italy. J. Hazard. Mater. 2019, 361, 103-110. [CrossRef] [PubMed]

76. Rivera-Jaimes, J.A.; Postigo, C.; Melgoza-Alemán, R.M.; Aceña, J.; Barceló, D.; López de Alda, M. Study of pharmaceuticals in surface and wastewater from Cuernavaca, Morelos, Mexico: Occurrence and environmental risk assessment. Sci. Total Environ. 2018, 613-614, 1263-1274. [CrossRef]

77. Fabrega, F.; Kumar, V.; Schuhmacher, M.; Domingo, J.L.; Nadal, M. PBPK modeling for PFOS and PFOA: Validation with human experimental data. Toxicol. Lett. 2014, 230, 244-251. [CrossRef]

78. Kortenkamp, A.; Backhaus, T.; Faust, M. State of the Art Report on Mixture Toxicity. 2009. Available online: http://ec.europa.eu/ environment/chemicals/effects/pdf/report_mixture_toxicity.pdf (accessed on 20 July 2020).

79. Technical Guidance Document on Risk Assessment in Support of Commission Directive 93/67/EEC on Risk Assessment for New Notified Substances and Commission Regulation (EC) No. 1488/94 on Risk Assessment for Existing Substances. Part II. EUR 20418 EN/2. European Chemicals Bureau Part II. Available online: https:/ / echa.europa.eu/documents/10162/16960216 /tgdpart2_2ed_en.pdf (accessed on 25 August 2020).

80. Wu, D.; Zhou, Y.; Lu, G.; Hu, K.; Yao, J.; Shen, X.; Wei, L. The occurrence and risks of selected emerging pollutants in drinking water source areas in Henan, China. Int. J. Environ. Res. Public Health 2019, 16, 4109. [CrossRef]

81. Thomaidi, V.S.; Matsoukas, C.; Stasinakis, A.S. Risk assessment of triclosan released from sewage treatment plants in European rivers using a combination of risk quotient methodology and Monte Carlo simulation. Sci. Total Environ. 2017, 603, 487-494. [CrossRef] [PubMed]

82. Isidori, M.; Lavorgna, M.; Nardelli, A.; Pascarella, L.; Parrella, A. Toxic and genotoxic evaluation of six antibiotics on non-target organisms. Sci. Total Environ. 2005, 346, 87-98. [CrossRef]

83. Lopez-Doval, J.C.; Montagner, C.C.; Fernandes Alburquerque, A.; Moschini-Carlos, V.; Umbuzeiro, G.; Pompeo, M. Nutrients, emerging pollutants and pesticides in a tropical urban reservoir: Spatial distributions and risk assessment. Sci. Total Environ. 2017, 575, 1307-1324. [CrossRef]

84. Zhou, S.; Di Paolo, C.; Wu, X.; Shao, Y.; Seiler, T.-B.; Hollert, H. Optimization of screening-level risk assessment and priority selection of emerging pollutants-The case of pharmaceuticals in European surface waters. Environ. Int. 2019, 128, 1-10. [CrossRef]

85. Yan, Z.; Liu, Y.; Yan, K.; Wu, S.; Han, Z.; Guo, R.; Chen, M.; Yang, Q.; Zhang, S.; Chen, J. Bisphenol analogues in surface water and sediment from the shallow Chinese freshwater lakes: Occurrence, distribution, source apportionment, and ecological and human health risk. Chemosphere 2017, 184, 318-328. [CrossRef]

86. Xiao, J.; Wang, L.; Deng, L.; Jin, Z. Characteristics, sources, water quality and health risk assessment of trace elements in river water and well water in the Chinese Loess Plateau. Sci. Total Environ. 2019, 650, 2004-2012. [CrossRef]

87. Hernando, M.D.; Mezcua, M.; Fernandez-Alba, A.R.; Barcelo, D. Environmental risk assessment of pharmaceutical residues in wastewater effluents, surface waters and sediments. Talanta 2006, 69, 334-342. [CrossRef]

88. Varjani, S.; Sudha, M.C. Occurrence and human health risk of micro-pollutants-A special focus on endocrine disruptor chemicals. In Current Developments in Biotechnology and Bioengineering. Emerging Organic Micro-Pollutants; Varjani, S., Tyagi, R.D., Larroche, C., Eds.; Elsevier: Amsterdam, The Netherlands, 2020; pp. 23-39. [CrossRef]

89. Fabrega, F.; Marquès, M.; Ginebreda, A.; Kuzmanovic, M.; Barceló, D.; Schuhmacher, M.; Domingo, J.L.; Nadal, M. Integrated Risk Index of Chemical Aquatic Pollution (IRICAP): Case studies in Iberian rivers. J. Hazard. Mater. 2013, 263P, 187-196. [CrossRef]

90. New and Emerging Water Pollutants Arising from Agriculture, Organisation for Economic Co-Operation and Development, Paris. Available online: https:/ /www.oecd.org/greengrowth/sustainable-agriculture/49848768.pdf (accessed on 16 August 2020).

91. Pereira, L.C.; de Souza, A.O.; Bernardes, M.F.F.; Pazin, M.; Tasso, M.J.; Pereira, P.H.; Dorta, D.J. A perspective on the potential risks of emerging contaminants to human and environmental Health. Environ. Sci. Pollut. Res. 2015, 22, 13800-13823. [CrossRef]

92. Carmalin, S.A.; Lima, E. Removal of emerging contaminants from the environment by adsorption. Ecotoxicol. Environ. Saf. 2018, 150, 1-17. [CrossRef]

93. de Oliveira, J.F.; Fia, R.; Rodrigues, F.N.; Fia, F.R.L.; de Matos, M.P.; Siniscalchi, L.A.B.; Sanson, A.L. Quantification, removal and potential ecological risk of emerging contaminants in different organic loads of swine wastewater treated by integrated biological reactors. Chemosphere 2020, 260, 127516. [CrossRef] [PubMed]

94. Lopera, A.E.-C.; Ruiz, S.G.; Alonso, J.M.Q. Removal of emerging contaminants from wastewater using reverse osmosis for its subsequent reuse: Pilot plant. J. Water Process. Eng. 2019, 29, 100800. [CrossRef]

95. Mohapatra, D.P.; Kirpalani, D.M. Advancement in treatment of wastewater: Fate of emerging Contaminants. Can. J. Chem. Eng. 2019, 97, 2621-2631. [CrossRef] 
96. Buttiglieri, G.; Knepper, T.P. Removal of Emerging Contaminants in Wastewater Treatment: Conventional Activated Sludge Treatment. In Emerging Contaminants from Industrial and Municipal Waste. The Handbook of Environmental Chemistry; Barceló, D., Petrovic, M., Eds.; Springer: Berlin/Heidelberg, Germany, 2008; Volume 5. [CrossRef]

97. Ji, J.; Kakade, A.; Yu, Z.; Khan, A.; Liu, P.; Li, X. Anaerobic membrane bioreactors for treatment of emerging contaminants: A review. J. Environ. Manag. 2020, 270, 110913. [CrossRef]

98. Fast, S.A.; Gude, V.G.; Truax, D.D.; Martin, J.; Magbanua, B.S. A critical evaluation of advanced oxidation processes for emerging contaminants removal. Environ. Process 2017, 4, 283-302. [CrossRef]

99. Rossner, A.; Shane, A.; Snyder, S.A.; Knappe, D.R.U. Removal of emerging contaminants of concern by alternative adsorbents. Water Res. 2009, 43, 3787-3796. [CrossRef]

100. Ahmed, M.B.; Zhou, J.L.; Ngo, H.H.; Guo, W.; Thomaidis, N.S.; Xu, J. Progress in the biological and chemical treatment technologies for emerging contaminant removal from wastewater: A critical review. J. Hazard. Mater. 2017, 323, 274-298. [CrossRef]

101. Avila, C.; Reyes, C.; Bayona, J.M.; Garcia, J. Emerging organic contaminant removal depending on primary treatment and operational strategy in horizontal subsurface flow constructed wetlands: Influence of redox. Water Res. 2013, 47, 315-325. [CrossRef] [PubMed]

102. Vymazal, J. Long-term performance of constructed wetlands with horizontal subsurface flow: Ten case studies from the Czech Republic. Ecol. Eng. 2011, 37, 54-63. [CrossRef]

103. Chen, Y.; Vymazal, J.; Březinov, T.; Koželuh, M.; Kule, L.; Huang, J.; Chen, Z. Occurrence, removal and environmental risk assessment of pharmaceuticals and personal care products in rural wastewater treatment wetlands. Sci. Total Environ. 2016, 566-567, 1660-1699. [CrossRef]

104. Gorito, A.M.; Ribeiro, A.R.; Almeida, C.M.R.; Silva, A.M.T. A review on the application of constructed wetlands for the removal of priority substances and contaminants of emerging concern listed in recently launched EU legislation. Environ. Pollut. 2017, 227, 428-443. [CrossRef]

105. Reyes-Contreras, C.; Hijosa-Valsero, M.; Sidrach-Cardona, R.; Bayona, J.M.; Becares, E. Temporal evolution in PPCP removal from urban wastewater by constructed wetlands of different configuration: A medium-term study. Chemosphere 2012, 88, 161-167. [CrossRef]

106. Hijosa-Valsero, M.; Matamoros, V.; Pedescoll, A.; Martín-Villacorta, J.; Bécares, E.; García, J.; Bayona, J.M. Evaluation of primary treatment and loading regimes in the removal of pharmaceuticals and personal care products from urban wastewaters by subsurface-flow constructed wetlands. Int. J. Environ. Anal. Chem. 2010, 91, 632-653. [CrossRef]

107. Hijosa-Valsero, M.; Matamoros, V.; Sidrach-Cardona, R.; Martín-Villacorta, J.; Bécares, E.; Bayona, J.M. Comprehensive assessment of the design configuration of constructed wetlands for the removal of pharmaceuticals and personal care products from urban wastewaters. Water Res. 2011, 44, 3669-3678. [CrossRef]

108. Matamoros, V.; Bayona, J.M. Behavior of Emerging Pollutants in Constructed Wetlands. In The Handbook of Environmental Chemistry; Barceló, D., Kostianoy, A.G., Eds.; Springer: Berlin/Heidelberg, Germany, 2008; Volume 5, pp. 199-217, Part S/2.

109. Llorens, E.; Matamoros, V.; Domingo, V.; Bayona, J.M.; García, J. Water quality improvement in a full-scale tertiary constructed wetland: Effects on conventional and specific organic contaminants. Sci. Total Environ. 2009, 407, 2517-2524. [CrossRef]

110. Zhang, D.Q.; Tan, S.K.; Gersberg, R.M.; Sadreddini, S.; Zhu, J.; Tuan, N.A. Removal of pharmaceutical compounds in tropical constructed wetlands. Ecol. Eng. 2011, 37, 460-464. [CrossRef]

111. Matamoros, V.; Caselles-Osorio, A.; Garcia, J.; Bayona, J.M. Behaviour of pharmaceutical products and biodegradation intermediates in horizontal subsurface flow constructed wetland. A microcosm experiment. Sci. Total. Environ. 2008, 394, 171-176. [CrossRef]

112. Song, H.L.; Nakano, K.; Taniguki, T.; Nomura, M.; Nishimura, O. Estrogenal removal from treated municipal effluent in small scale constructed wetlands with different depth. Bioresour. Technol. 2009, 100, 2945-2951. [CrossRef]

113. Breitholtz, M.; Naslund, M.; Strae, D.; Borg, H. An evaluation of free water surface wetlands as tertiary sewage water treatment of micro-pollutants. Ecotoxicol. Environ. Saf. 2012, 78, 63-71. [CrossRef]

114. Ranieri, E.; Verlicchi, P.; Young, T.M. Paracetamol removal in subsurface flow constructed wetlands. J. Hydrol. 2011, 404, 130-135. [CrossRef]

115. Matamoros, V.; Arias, C.; Brix, H.; Bayona, J.M. Preliminary screening of small-scale domestic wastewater treatment systems for removal of pharmaceutical and personal care products. Water Res 2009, 43, 55-62. [CrossRef]

116. Matamoros, V.; Salvado, V. Evaluation of the seasonal performance of a water reclamation pond-constructed wetland system for removing emerging contaminants. Chemosphere 2012, 86, 111-117. [CrossRef]

117. Agudelo, R.M.; Penuela, G.; Aguirre, N.J.; Moratod, J.; Jaramill, M.L. Simultaneous removal of chlorpyrifos and dissolved organic carbon using horizontal sub-surface flow pilot wetlands. Ecol. Eng. 2010, 36, 1401-1408. [CrossRef]

118. Shelef, O.; Gross, A.; Rachmilevitch, S. Role of plants in a constructed wetland: Current and new perspectives. Water 2013, 5, 405-419. [CrossRef]

119. Chen, C.; Guo, W.; Ngo, H.H.; Lee, D.-J.; Tung, K.-L.; Jin, P.; Wang, J.; Wu, Y. Challenges in biogas production from anaerobic membrane bioreactors. Renew. Energy 2016, 98, 120-134. [CrossRef]

120. Zhang, J.; Xiao, K.; Huang, X. Full-scale MBR applications for leachate treatment in China: Practical, technical, and economic features. J. Hazard. Mater. 2020, 389, 122138. [CrossRef] 
121. Tran, N.H.; Chen, H.; Reinhard, M.; Mao, F.; Gin, K.Y.H. Occurrence and removal of multiple classes of antibiotics and antimicrobial agents in biological wastewater treatment processes. Water Res. 2016, 104, 461-472. [CrossRef]

122. Khan, N.A.; Khan, S.U.; Sirajuddin, K.; Ahmed, S.; Farooqi, I.H.; Yousefi, M.; Mohammadi, A.A.; Changani, F. Recent trends in disposal and treatment technologies of emerging-pollutants-A critical review. Trends Anal. Chem. 2020, 115744. [CrossRef]

123. Lin, H.; Peng, W.; Zhang, M.; Chen, J.; Hong, H.; Zhang, Y. A review on anaerobic membrane bioreactors: Applications, membrane fouling and future perspectives. Desalination 2013, 314, 169-188. [CrossRef]

124. Dereli, R.K.; Ersahin, M.E.; Ozgun, H.; Ozturk, I.; Jeison, D.; van der Zee, F.P.; van Lier, J.B. Potentials of anaerobic membrane bioreactors to overcome treatment limitations induced by industrial wastewaters. Bioresour. Technol. 2012, 122, 160-170. [CrossRef] [PubMed]

125. Wang, A.J.; Li, W.W.; Yu, H.Q. Advances in biogas technology. Adv. Biochem. Eng. Biotechnol. 2012, 128, 119-141. [CrossRef]

126. Stuckey, D.C. Recent developments in anaerobic membrane reactors. Bioresour. Technol. 2012, 122, 137-148. [CrossRef]

127. Guo, W.; Khan, M.A.; Ngo, H.H.; Johir, M.A.H.; Nghiem, L.D.; Ni, B.-J. Anaerobic Membrane Bioreactors-An Introduction. In Current Developments in Biotechnology and Bioengineering; Ngo, H.H., Guo, W., Ng, H.Y., Mannina, G., Pandey, A., Eds.; Elsevier: Amsterdam, The Netherlands, 2020; pp. 1-24.

128. Meng, F.G.; Chae, S.R.; Drews, A.; Kraume, M.; Shin, H.S.; Yang, F.L. Recent advances in membrane bioreactors (MBRs): Membrane fouling and membrane material. Water Res. 2009, 43, 1489-1512. [CrossRef] [PubMed]

129. Morrow, C.P.; McGaughey, A.L.; Hiibel, S.R.; Childress, A.E. Submerged or sidestream? The influence of module configuration on fouling and salinity in osmotic membrane bioreactors. J. Membr. Sci. 2018, 548, 583-592. [CrossRef]

130. Maaz, M.; Yasin, M.; Aslam, M.; Kumar, G.; Atabani, A.E.; Idrees, M.; Anjum, F.; Jamil, F.; Ahmad, R.; Khan, A.L.; et al. Anaerobic membrane bioreactors for wastewater treatment: Novel configurations, fouling control and energy considerations. Bioresour. Technol. 2019, 283, 358-372. [CrossRef]

131. Shin, C.; Bae, J. Current status of the pilot-scale anaerobic membrane bioreactor treatments of domestic wastewaters: A critical review. Bioresour. Technol. 2018, 247, 1038-1046. [CrossRef] [PubMed]

132. Hu, Y.; Xiaochang, C.; Wang, X.C.; Ngo, H.H.; Sun, Q.; Yan, Y. Anaerobic dynamic membrane bioreactor (AnDMBR) for wastewater treatment: A review. Bioresour. Technol. 2018, 247, 1107-1118. [CrossRef]

133. Katuri, K.P.; Werner, C.M.; Jimenez-Sandoval, R.J.; Chen, W.; Jeon, S.; Logan, B.E.; Lai, Z.; Amy, G.L.; Saikaly, P.E. A novel anaerobic electrochemical membrane bioreactor (AnEMBR) with conductive hollow-fiber membrane for treatment of low-organic strength solutions. Environ. Sci. Technol. 2014, 48, 12833-12841. [CrossRef]

134. Monsalvo, V.M.; McDonald, J.A.; Khan, S.J.; Le-Clech, P. Removal of trace organics by anaerobic membrane bioreactors. Water Res. 2014, 49, 103-112. [CrossRef] [PubMed]

135. Wijekoon, K.C.; McDonald, J.A.; Khan, S.J.; Hai, F.I.; Price, W.E.; Nghiem, L.D. Development of a predictive framework to assess the removal of trace organic chemicals by anaerobic membrane bioreactor. Bioresour. Technol. 2015, 189, 391-398. [CrossRef]

136. Song, X.; McDonald, J.; Price, W.E.; Khan, S.J.; Hai, F.I.; Ngo, H.H.; Guo, W.; Nghiem, L.D. Effects of salinity build-up on the performance of an anaerobic membrane bioreactor regarding basic water quality parameters and removal of trace organic contaminants. Bioresour. Technol. 2016, 216, 399-405. [CrossRef]

137. Huang, B.; Wang, H.-C.; Cui, D.; Zhang, B.; Chen, Z.-B.; Wang, A.-J. Treatment of pharmaceutical wastewater containing $\beta$-lactams antibiotics by a pilot-scale anaerobic membrane bioreactor (AnMBR). Chem. Eng. J. 2018, 341, 238-247. [CrossRef]

138. Periyaraman, P.M.; Karan, S.; Ponnusamy, S.K.; Vaidyanathan, V.; Vasanthakumar, S.; Dhanasekaran, A.; Subramanian, S. Adsorption of an anionic dye onto native and chemically modified agricultural waste. Environ. Eng. Manag. J. 2019, 18, 257-270. [CrossRef]

139. Hlihor, R.-M.; Figueiredo, H.; Tavares, T.; Gavrilescu, M. Biosorption potential of dead and living Arthrobacter viscosus biomass in the removal of Cr(VI): Batch and column studies. Process Saf. Environ. Prot. 2017, 108, 44-56. [CrossRef]

140. Adewuyi, A. Chemically modified biosorbents and their role in the removal of emerging pharmaceutical waste in the water system. Water 2020, 12, 1551. [CrossRef]

141. Nguyen, L.N.; Hai, F.I.; Yang, S.; Kang, J.; Leusch, F.D.L.; Roddick, F.; Price, W.E.; Nghiem, L.D. Removal of pharmaceuticals, steroid hormones, phytoestrogens, UV-filters, industrial chemicals and pesticides by Trametes versicolor: Role of biosorption and biodegradation. Int. Biodeterior. Biodegrad. 2014, 88, 169-175. [CrossRef]

142. Chaukura, N.; Gwenzi, W.; Tavengwa, N.; Manyuchi, M.M. Biosorbents for the removal of synthetic organics and emerging pollutants: Opportunities and challenges for developing countries. Environ. Dev. 2016, 19, 84-89. [CrossRef]

143. Bernhard, M.; Müller, J.; Knepper, T.P. Biodegradation of persistent polar pollutants in wastewater: Comparison of an optimised lab-scale membrane bioreactor and activated sludge treatment. Water Res. 2006, 40, 3419-3428. [CrossRef] [PubMed]

144. Nguyen, L.N.; Hai, F.I.; Kang, J.; Price, W.E.; Nghiem, L.D. Removal of emerging trace organic contaminants by MBR-based hybrid treatment processes. Int. Biodeter. Biodegr. 2013, 85, 474-482. [CrossRef]

145. Dolar, D.; Gros, M.; Rodriguez-Mozaz, S.; Moreno, J.; Comas, J.; Rodriguez-Roda, I.; Barceló, D. Removal of emerging contaminants frommunicipal wastewater with an integrated membrane system, MBR-RO. J. Hazard. Mater. 2012, 239, 64-69. [CrossRef] [PubMed]

146. Sahar, E.; David, I.; Gelman, Y.; Chikurel, H.; Aharoni, A.; Messalem, R.; Brenner, A. The use of RO to remove emerging micropollutants following CAS/UF or MBR treatment of municipal wastewater. Desalination 2011, 273, 142-147. [CrossRef] 
147. Ensano, B.M.B.; Borea, L.; Naddeo, V.; de Luna, M.D.G.; Belgiorno, V. Control of emerging contaminants by the combination of electrochemical processes and membrane bioreactors. Environ. Sci. Pollut. Res. 2019, 26, 1103-1112. [CrossRef] [PubMed]

148. Kim, T.H.; Kim, S.D.; Kim, H.Y.; Lim, S.J.; Lee, M.; Yu, S. Degradation and toxicity assessment of sulfamethoxazole and chlortetracycline using electron beam, ozone and UV. J. Hazard. Mater. 2012, 227, 237-242. [CrossRef]

149. Melo-Guimaraes, A.; Torner-Morales, F.J.; Durán-Álvarez, J.C.; Jiménez-Cisneros, B.E. Removal and fate of emerging contaminants combining biological, flocculation and membrane treatments. Water Sci. Technol. 2013, 67, 877-885. [CrossRef] [PubMed]

150. Ibanez, M.; Gracia-Lor, E.; Bijlsma, L.; Morales, E.; Pastor, L.; Hernández, F. Removal of emerging contaminants in sewage water subjected to advanced oxidation with ozone. J. Hazard. Mater. 2013, 260, 389-398. [CrossRef] [PubMed]

151. Reungoat, J.; Escher, B.; Macova, M.; Argaud, F.; Gernjak, W.; Keller, J. Ozonation and biological activated carbon filtration of wastewater treatment plant effluents. Water Res. 2012, 46, 863-872. [CrossRef] [PubMed] 